\title{
DIRETIVAS ANTECIPADAS DE VONTADE - TESTAMENTO VITAL: APLICAÇÃO DO FUNDAMENTO CONSTITUCIONAL DA DIGNIDADE DA PESSOA HUMANA
}

PREVIOUS DIRECTIONS OF WILL - VITAL TESTAMENT: APPLICATION OF THE CONSTITUTIONAL FOUNDATION OF THE DIGNITY OF THE HUMAN PERSON

Lene Revoredo GOUVEIA ${ }^{1}$

ISSUE DOI: $10.21207 / 1983.4225 .515$

\footnotetext{
${ }^{1}$ Doutorado em Educação (2007) - UFRJ. Doutorado em Medicina (1995) - UFRJ. Mestrado em Medicina (1976) - UERJ. Graduação em Medicina e Direito. Médica. Advogada. Especialização em Direito Civil Geral (2014) - Universidade ANHAN-GUERA - UNIDERP. Especialização em Direito Constitucional (2016) Universidade ANHANGUERA - UNIDERP. Professora Assistente da Faculdade Presbiteriana Mac-kenzie-Rio (atual). Ex- Professora Assistente da Faculdade de Ciências Médicas - UERJ. Ex- Professora Adjunto da Faculdade de Medicina UFRJ. Especialização em Perícia Criminal (2013) - UCB. Especialização em Acupuntura (1998) - IARJ. Especiali-zação em História da Arte e Arquitetura no Brasil (1997) - PUC/RJ
} 


\section{RESUMO}

As Diretivas Antecipadas de Vontade do Paciente (Resolução CFM 1995/2012) lhe permitem manifestar, prévia e expressamente, seus desejos, no que se refere ao tratamento médico desejado, em momentos finais de sua existência, quando não mais se encontre capaz de exprimir sua vontade de forma livre e autônoma, no que tange a medidas terapêuticas desproporcionais, que apenas prolongam seus sofrimentos, sem que delas aufira benefícios. Trata-se a citada Resolução, a nosso ver, de um contrato de prestação de serviços médicos, em que se observam duas manifestações de vontade contrapostas - a do paciente e a do médico - unidas em uma única declaração de vontade, que tem, como objetivo precípuo, o respeito à dignidade da pessoa humana. Nessa declaração, o paciente manifesta o direito de exercer livremente o Princípio da Autonomia do Paciente, baseado no Fundamento Constitucional da Dignidade da Pessoa Humana e o médico, o direito de exercer o Princípio do Imperativo de Consciência, igualmente inscrito em nossa Lei Maior. Tal contrato atende a sua função social no que concerne ao respeito e solidariedade entre as partes, bem assim na influência sobre a sociedade em geral, quanto à compreensão do que seja a morte digna. Como um contrato de prazo indeterminado, poderá cada uma das partes promover, a qualquer momento, sua resilição unilateral, em prazo justo, atendendo ao princípio legal da boa-fé objetiva. Sua forma deverá ser expressa e sugerimos que o seja em instrumento particular, apensado ao prontuário do paciente ou a sua ficha médica. O termo Diretivas Antecipadas de Vontade nos parece mais adequado do que Testamento Vital, desde que se trata de um acordo de vontades, diverso do testamento, um negócio jurídico unilateral, composto de uma única vontade.

Palavras-chave: Diretivas Antecipadas de Vontade. Resolução CFM 1995/12. Dignidade da Pessoa Humana. Princípio da Autonomia do Paciente. Princípio do Imperativo de Consciência do Médico. Testamento Vital. Contrato de Prestação de Serviços Médicos. Função Social do Contrato. Forma Expressa. Documento Particular. Registro em Prontuário ou Ficha Médica.

\section{ABSTRACT}


Advance care documents (Resolução CFM 1995/2006) allow patients carrying life-threatening diseases to determine previously the medical treatment they wish to receive in their final moments, as well as to refuse certain specific therapys that can be useless and obstinate measures only to extend their suffering and not improving their life quality, at a moment in their lives when they don't have the capacity to express their wishes anymore. This document, in our point of view, represents a medical services agreement, or else, a contract, between two competent parties - patient and his physician - together in one single "meeting of minds", in order to respect the constitutional principle of Human Dignity. So the patient has the plain exercise about the Patient Autonomy Right and the doctor has, on his turn, the right to the constitutional protection of his consciousness freedom. This contract atends its social function due to the sympathy and respect between patient and psysician and the attention due to the family, as well as its influence on the society as a whole, bringing meaning to the expression. "death with dignity". As a contract with no time limit, each party can breach the agreement, in a fair moment, attending to the implied principle of Good Faith. We understand this document must be in a written form, inserted into the patient pronctuary and medical records at the hospital or in the doctor's office.

Keywords: Advance Care Documents. Resolução CFM 1995/2012. Human Dignity. Patient's Autonomy Right. Doctor's Consciousness Freedom. Contract Services Agreement. Contract Social Function. Press and Private Document. Posted on the Medical Records.

\section{NOTA INTRODUTÓRIA}

A Resolução 1955, do Conselho Federal de Medicina, de 31 de agosto de 2012, intitulada Diretivas Antecipadas de Vontade dos Pacientes, interessou-me sobremaneira desde os primeiros momentos de sua publicação. Ela veio ao encontro das inúmeras dúvidas que cercam paciente e médico, naqueles instantes tão difíceis para ambos: os que envolvem a terminalidade da vida, seja num leito de hospital, seja no aconchego do lar, terminalidade essa mais comumente observada no decorrer de uma doença consuntiva crônica, mas, também, causada por incidentes agudos inesperados e incapacitantes. 
Tais condições mórbidas não poupam idade, sexo, ocupações. Atingem-nos a todos em diferentes graus, mas sempre demandando orientações, por vezes difíceis de serem compreendidas ou, até mesmo, seguidas.

Esse pequeno trabalho representa um amálgama de dois trabalhos anteriores, apresentados, em momentos diversos (2013 e 2015), ao final de Cursos de Especialização na área do Direito e bibliografia atualizada.

O primeiro, intitulado: Diretivas Antecipadas de Vontade: um contrato de vida digna, procurou demonstrar, como lembra o título, que o documento escrito pelo paciente, determinando as medidas terapêuticas que lhe devem e as que não lhe devem ser prestadas, nos momentos que antecederem os seus instantes finais, nada mais é que um contrato de prestação de serviços médicos, em que a parte credora - o paciente - determina a obrigação a ser cumprida e a parte devedora - o médico - a cumpre, recebendo da parte credora o que lhe é devido em contraprestação, na melhor linha da autonomia privada, como entende o nosso Novo Direito Civil.

O segundo, denominado Diretivas Antecipadas de Vontade: o direito fundamental ao imperativo de consciência do médico, diz respeito àqueles profissionais que apresentam resistência em obedecer às diretivas determinadas pelo paciente para seu final de vida, por convicções pessoais, morais ou religiosas. Tais profissionais estão protegidos pelo direito fundamental constitucional que os assiste, ao alegar imperativo de consciência, quando serão substituídos por colegas que não apresentem tais objeções. Entretanto, lembrando que permanecerão atentos aos cuidados paliativos, indicados para o paciente em questão.

Entendemos a Resolução 1995, do CFM, como um alento, mesmo que temporário, para essas situações finais, bem assim um incentivo para que a sociedade clame por uma normatização, preenchendo, assim, uma lacuna que não mais deve permanecer em nosso ordenamento jurídico.

\section{INTRODUÇÃO}

Vivemos cada vez por mais tempo, o que nos torna mais produtivos e felizes, mais conscientes do mundo a nossa volta, mais atentos às inovações tecnológicas que transformam nossas interações humanas, fazendo-nos cada vez mais humanos, mais ativos, mais vivos, mais lúcidos 
quanto a nossa condição de mortais e do que nos espera nesses momentos, por isso precisamos poder abreviar a vida!

Abreviar a vida? Mas... não há aí um paradoxo?

Entretanto, se por outro lado pensarmos que existem momentos em que a vida não é mais tão vida? Em que o corpo apenas ali está, sem que nenhum dos maravilhosos métodos terapêuticos aplicados apresentem mais quaisquer resultados, trazendo-lhe nada mais que sofrimentos, sem nenhum sentido para o indivíduo, que somente quer momentos de paz com seus familiares?

Eis que, surge, nesse instante, a compreensão, de que, claramente, estamos frente a mais de um tipo de vida!

Mas... qual vida precisamos abreviar? De que vida se trata? Da que enfrentamos desde o nascimento, com suas alegrias, dissabores, vitórias, frustrações, amizades, desconhecimentos, confortos, abandonos, aleivosias, sabedorias e do que mais nos aguarda nesse paulatino caminhar do tempo? Da vida que, apesar do que imaginamos iremos enfrentar, apesar da certeza da finitude que trazemos em nosso DNA, não desejamos nunca deixar, porque o verdadeiro terror do desconhecido que nos espera ao final da jornada, somente se nos apresenta, em toda sua pujança, nesse momento já sem volta? Não, não, certamente, não é essa a vida que podemos desejar abreviar.

Nós a queremos com afinco, por ela vivemos, morremos e até mesmo matamos!

A vida que pensamos, ou mesmo, por vezes, precisamos abreviar, trata-se daquela vida sem vida, da vida sem mais perspectivas, permeada de sofrimentos físicos indizíveis, de sofreres morais, psicológicos, sentimentais, em um cérebro consciente de que tais sofreres e sensações se encontram assentados em um corpo depauperado, deteriorado, até certo ponto já morto, cujas medidas terapêuticas somente lhe agravam os sofrimentos, pois que a elas não mais responde, não são mais recebidas com esperança, mas com negação, mesmo com raiva, pela incompreensão de sua terminalidade por todos que o cercam e que acreditam estar-lhe fazendo um bem, quando na verdade estão tratando a si próprios, expiando suas próprias culpas e tentando exorcizar seus medos..

Mas, por que nos preocuparmos em distinguir esses tipos de vida, se é tudo parte natural de uma existência humana, se desde o início dos tempos nascemos, vivemos e morremos, se disso temos pleno conhecimento, embora com profundidades diferentes conforme nosso, chamemos, 
preparo emocional, mesmo porque na hora final somos todos absolutamente iguais e disso não há fuga possível?

Porque, embora saibamos de nossa impotência em conter o desenvolver de nossa vida e seu êxito final, essa distinção nos é necessária, por estamos frente a uma realidade, por nós construída, realidade essa que, ao mesmo tempo em que nos salva para uma vida que valha a pena ser vivida, pode empurrar-nos para uma vida sombria, sem nortes, sem perspectivas, velada pelos sofrimentos sem benefício, frequentemente distante do aconchego familiar e abandonada aos ruídos contínuos e insensíveis de máquinas desconectadas dos sentimentos humanos.

Trata-se do desenvolvimento tecnológico da atualidade, que possibilita a manutenção da vida muito além do que era esperado, até então, para a existência humana. Esses maravilhosos recursos tecnológicos de que dispomos nos dias que correm, permitindo que inúmeras vidas sejam salvas e que os pacientes possam reintegrar-se plenamente à sociedade a que pertencem, também apresentam um outro lado não tão alvissareiro para um determinado tipo de pacientes.

Falamos aqui daqueles pacientes chamados "terminais", vítimas de doenças gravíssimas, que se espalham pelos seus vários órgãos, comprometendo-lhes irreversivelmente as funções, ou que se encastelam em seus cérebros, não mais lhes permitindo, assim, qualquer manifestação de vida de relação, ou seja, alijando-os completamente de qualquer existência humana digna.

Submeter tais pacientes, contra a sua vontade, enquanto lúcida e desprovida de qualquer tipo de indução, a tratamentos torturantes e desnecessários para a sua cura ou alívio de seus sofrimentos, sobretudo quando eles já tenham manifestado, clara e objetivamente, as suas discordâncias em realizá-los, vai de encontro ao direito à autonomia do paciente e, consequentemente, a uma vida digna até a sua morte, vida digna esta, representada, não apenas pelos cuidados paliativos indicados em seu caso, como, principalmente, pela convivência merecida junto a seus familiares.

Impende destacar que não estamos tratando de eutanásia, situação em que se propugna provocar a morte nos casos de pacientes já sem nenhuma esperança de resultados, com a aplicação dessas medidas terapêuticas invasivas. O que discutimos é a ortotanásia, comportamento que se caracteriza pelo respeito aos desejos do paciente de morrer em paz, sem se submeter a tratamentos por demais invasivos, com grandes sofrimentos e que se caracterizam por lhe oferecer quaisquer benefícios. Procura-se, 
com a ortotanásia, substituir a distanásia, entendida esta como aquela conduta que não pretende desistir de tratamentos heroicos, ou seja, sem quaisquer benefícios, mesmo que contra a vontade do paciente, apenas para não deixar de "tratar".

Eis que uma situação nova surge, em que esses pacientes, exercendo seu reconhecido direito à autonomia de sua vontade, podem recusarse, em pleno estado de lucidez, a submeter-se àquelas medidas terapêuticas, já reconhecidas, na ocasião, como completamente inócuas em seu caso.

Tal situação encontra amparo objetivo na Resolução no 1.995 , do Conselho Federal de Medicina, publicada no Diário Oficial da União, em 31 de agosto de 2012, (anexo 1) que dispõe sobre as Diretivas Antecipadas de Vontade dos Pacientes (Testamento Vital, para a doutrina jurídica brasileira).

Entendemos, por outro lado, que esta nova situação jurídica, em que o paciente, por manifestação de vontade ainda livre e desimpedida, prenhe de significados na relação médico-paciente, exprime seus desejos sobre cuidados e tratamentos a lhe serem prestados, quando não mais possa expressá-los de livre e desimpedida vontade, deverá implicar em consequências jurídicas importantes no bojo dessa relação, bem assim, nas relações familiares e na sociedade como um todo.

Trata-se, essa Resolução, a nosso ver, de um contrato de prestação de serviços médicos, em que as partes, paciente e médico, estarão em consonância quanto á autonomia do paciente em expressar sua decisão de não desejar ser submetido a técnicas terapêuticas consideradas excepcionais e heroicas para o seu caso, das quais não mais se beneficiará, submetendo-se, consequentemente, a métodos paliativos de tratamento ou tratamento conservador. O papel do médico, por seu turno, reveste-se de notória importância nessa ocasião, visto que não só deverá indicar o momento em que não mais se irão obter benefícios com tais técnicas, como deverá ser o responsável pelos cuidados terapêuticos paliativos a serem ministrados ao paciente.

Tal contrato, na interpretação do nosso Novo Direito Civil Constitucional, deve obedecer, compulsoriamente, ao Princípio da Função Social, um princípio que atua na essência do conteúdo contratual, permitindo, assim, a proteção dos próprios contratantes, principalmente, no caso em discussão, quanto à ideia errônea de eutanásia, seja esta passiva ou ativa, ainda presente em muitos de nós. 
Mais ainda, trata-se de um Princípio que vem extrapolar os limites contratuais para interessar à própria sociedade, afetando, em primeiro plano, os familiares do contratante, mas também envolvendo, de forma significativamente importante, um valor social que impregna o que se poderia chamar de imaginário social, qual seja, o dever de se perseguir a vida a qualquer custo, de todas as formas, e sempre, mesmo quando essa mesma vida não mais se possa definir como tal.

Nosso trabalho visa, como seu objeto, apresentar as Diretivas Antecipadas de Vontade como um contrato de prestação de serviços médicos, em que ambas as partes, paciente e profissional médico, manifestam suas vontades que, embora contrapostas, rumam num sentido único, em uma declaração de vontade única, expressa num documento médico, a ser cumprida em momento próprio.

Contrato especial em que ambas as partes comportam-se ativamente, gerando obrigações: o paciente, no exercício do seu direito à autonomia, declarará sua vontade quanto à terapêutica a ser recebida, ou não, em seus momentos finais de vida, aguardando, evidentemente, o diagnóstico do médico quanto à sua terminalidade; o médico obrigar-se-á, não somente a informar correta e completamente o paciente sobre o verdadeiro estado em que este se encontra, como diagnosticar a presença desses momentos finais, verificar a eticidade da decisão tomada pelo paciente e aplicar o tratamento paliativo, ou seja, o tratamento conservador indicado.

Igualmente abordamos o papel do profissional médico no atendimento aos desejos do paciente, nesses momentos terminais, reconhecendo a esse profissional o exercício do direito fundamental ao imperativo de consciência, previsto no texto de nossa Constituição da República. Nesses momentos, esse médico não pode ser impedido de obedecer aos ditames de sua consciência, deixando, então, aos cuidados de outro profissional, que não se sinta impedido de os atender, sem, entretanto, deixar de prestar todos os cuidados médicos paliativos que se fizerem necessários.

Representam, portanto, as Diretivas Antecipadas de Vontade o documento por excelência no que se refere ao reconhecimento do princípio da dignidade da pessoa humana, celebrado no terceiro fundamento da nossa Lei Maior. Seu estudo reveste-se de vital importância no atuar diário, tanto do profissional médico, como de todos aqueles que trabalham na área do Direito, com destaque para o advogado, já que será ele, certamente, o primeiro a ser procurado pelos que venham a discordar da realização dos direitos expressos pelo paciente. 


\section{A VIDA COMO BEM MAIOR OU A VIDA COMO OBRIGAÇÃO- DEVER?}

A inviolabilidade do direito à vida encontra guarida no caput do artigo 5ํㅡㄹ de nossa Lei Maior. Trata-se de um direito que, embora garantido pelo nosso ordenamento jurídico, não concede ao seu titular o poder de dela, vida, dispor, devendo ele, por seu turno, conservá-la e exercê-la positivamente.

HANS JONAS, em sua obra $O$ Princípio Vida, nos mostra que, primitivamente, prevalecia a ideia de que "a vida encontrava-se por toda a parte e o ser confundia-se com o ser vivo". Dessa forma, a vida estava presente em tudo que o cercava, logo, se a vida é a regra, se a vida é o natural, a morte é a negação de tudo,"... o incompreensível, o que não devia ser verdadeiro". 2

Essa linha de pensamento, embora entendida como primitiva, encontra-se ainda presente em nosso imaginário, daí a quase obrigação de viver que nos assalta a todo tempo. Solidarizamo-nos com quem é preso de sofrimentos inenarráveis, mas o aconselhamos a suportá-los com paciência e dignidade, já que é essa a única forma de permanecer vivo, pois a morte deverá ser natural e a seu tempo, tempo esse, entretanto, indeterminado.

A vida apresenta-se para nós, como um direito absoluto, que não pode ser violado, nem mesmo pelo seu titular, que pode e deve exercê-lo, sem, entretanto, dele dispor no que tange à sua terminalidade, pois que dele não é realmente proprietário, já que não pode destruí-lo. E não é realmente proprietário, ouso pensar, porque, como parte da ideia primitiva de que há vida em toda a parte, terminar a sua própria vida é violar a vida de tudo e de todos, ideia que nos horroriza de tal maneira, que, já que não podemos criminalizar o suicida, criminalizamos quem o induz a tal ato.

$\mathrm{Na}$ atualidade, contudo, a consideração por alguns de que a vida apresenta-se como o bem maior, apontando-se, para tal, o fato de que figura em primeiro lugar no referido dispositivo constitucional, não "encontra qualquer fundamento jurídico em nosso sistema normativo. A Constituição de 1988 não reserva tratamento privilegiado à vida em face de outros interesses individuais". 3

2 JONAS, H. O Princípio Vida. Petrópolis: Vozes, 2004, p. 19.

${ }^{3}$ SCHREIBER, A. Direitos da Personalidade. São Paulo: Atlas, 2011., p. 51. 
Enquanto não se distingue essa maior valoração quanto ao direito à vida, no texto constitucional, expresso no caput do art. 5ํㅡ, em relação aos demais direitos individuais, como os direitos à liberdade, à honra, à igualdade, exemplificando-se, verifica-se que é conferida prioridade absoluta à dignidade da pessoa humana, terceiro fundamento da República, inscrita no inciso III, do artigo $1^{\circ}$ da Constituição. "Assim, nem a liberdade, nem a vida, nem qualquer dos direitos individuais recebe proteção absoluta. São protegidos apenas enquanto e na medida em que se dirigem à promoção da dignidade humana". 4

Tal entendimento é que nos permite compreender que o direito à vida, nesse novo pensar constitucional, encontra uma verdadeira subordinação à dignidade humana, falando-se, portanto"... em direito à vida digna, direito à vida com qualidade, não interessando à pessoa nem ao ordenamento jurídico apenas a simples garantia da sobrevivência física da pessoa, mas que esta esteja no mundo com um mínimo de dignidade." 5

Observa-se a preocupação explícita no que se refere ao direito à vida adjetivada, quando a um paciente é permitido escolher o tratamento médico a que irá se submeter ou até mesmo decidir-se a não aceitar tratamento algum, como dispõe o art. 15 do Código Civil Brasileiro, verbis: "Ninguém pode ser constrangido a submeter-se, com risco de vida, a tratamento médico ou a intervenção cirúrgic".

No mesmo sentido, assim se manifesta o atual Código de Ética Médica, de 13/04/2010, em seu artigo 31, verbis: "É vedado ao médico: Desrespeitar o direito do paciente ou de seu representante legal de decidir livremente sobre a execução de práticas diagnósticas ou terapêuticas, salvo em caso de iminente risco de morte".

Um aspecto importantíssimo merece ser evidenciado, já que, como o direito a uma vida digna é direito constitucionalmente protegido, mostra-se plenamente superada a distinção entre as noções de direitos da personalidade e direitos humanos, pois os princípios constitucionais, irradiando-se para todos os ramos do direito e alcançando as normas infraconstitucionais, ensejam uma clara permeabilidade no que tange à divisão clássica entre direito público e direito privado, como bem assinala FARIAS;

\footnotetext{
${ }^{4}$ SCHREIBER, A. Direitos da Personalidade. São Paulo: Atlas, 2011., p. 52.

${ }^{5}$ FARIAS, C.C. de \& ROSENVALD, N. Curso de Direito Civil: Parte Geral e

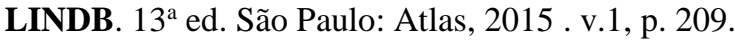


ROSENVALD: "Rompe-se a compreensão sectária da tutela da personalidade sob a ótica publicista ou privativista, como se fosse possível emprestar uma proteção parcial à pessoa humana sem martirizar o comando constitucional". 6

A vida, sem dúvida nenhuma, é um bem maior, mas, um bem acompanhado de qualificadores, em que a pessoa humana não é entendida apenas como uma maravilhosa máquina, que para estar viva precisa apenas de respirar, é imprescindível que sua vida tenha dignidade, para que possa exercer plenamente todos os direitos que sua humanidade lhe confere.

Como corolário de tal interpretação, encontramos o raciocínio jurídico contemporâneo quanto ao início da personalidade civil, em que se reconhece a quem ainda não nasceu e, portanto, não se separou do ventre materno, momento em que seria constatada a realidade do primeiro movimento respiratório e, assim, fosse considerado pessoa, o reconhecimento dos direitos de personalidade formais, que compreendem os direitos à vida, à pensão alimentícia, à imagem. Percebe-se, dessa forma, que delegar-se a apenas um mero respirar, movimento automático comandado pelo tronco cerebral, um poder de determinar que o nascituro ainda não tem direitos da personalidade, porque, obviamente, ainda não respirou, é em tudo contrário ao que dispõe a segunda parte do art. $2^{\underline{0}}$ do Código Civil, verbis: "A personalidade civil da pessoa começa do nascimento com vida, mas a lei põe a salvo, desde a concepção, os direitos do nascituro."(grifo nosso)

Entender que tais direitos são os direitos de personalidade formais, ou seja, aqueles extrapatrimoniais, consubstanciados nos direitos à vida, à pensão alimentícia, o direito a curador em casos de impossibilidade da mãe, a danos morais à imagem, e outros, é igualmente entender que o ato de respirar tem importância inconteste na aquisição dos direitos patrimoniais, em que poderá ser donatário, herdeiro e exercer seu direito à filiação, já que a certeza desta filiação exige aplicação de método considerado invasivo durante a gestação, devendo, portanto, aguardar-se o nascimento para que possa ser realizado.

Observa-se que a compreensão dos direitos do nascituro como formais e patrimoniais, conforme interpreta a Teoria Condicionalista, na melhor linha do Direito Contemporâneo Pós-Positivista, torna justo e possível reconhecer Direitos da Personalidade àquele que ainda não nasceu, ou seja, ainda não respirou.

${ }^{6}$ SCHREIBER, A. Direitos da Personalidade. São Paulo: Atlas, 2011., p. 52. 
Ao analisarmos a situação daquela pessoa, em pleno uso de suas faculdades mentais, que se sabe em estado terminal de doença grave incurável, que não mais é objeto de qualquer benefício de quaisquer medidas terapêuticas, estando ou não em seu leito de morte, no momento de sua decisão, mas tendo consciência de que caminha inexoravelmente para o final de sua vida, percebemos que esperar, obrigatoriamente, pelo seu último suspiro, coagindo-a a suportar medicamentos, agora desnecessários, e exames claramente invasivos, causadores de mais sofrimentos, é, indubitavelmente, retirar-lhe os direitos de personalidade formais, que, no entanto, concedemos ao ser que ainda não respirou!

Retiramos o seu direito à vida digna, o seu direito à imagem, qual seja o de morrer em paz com seus familiares, em lugar de tubos agressivos introduzidos em seu corpo, com a explicação de que lhe alimentam, lhe permitem continuar a respirar, por isso lhe conferem vida. Observe-se que não nos importa mais a presença do ato de respirar, para concedermos direitos de personalidade formais ao nascituro que ainda não respirou, mas que caminha para a vida, não obstante, os retiramos da pessoa que ainda respira, mas não nascerá, pois seu destino final é a morte!

Note-se: retiramos seus direitos e ela, a pessoa, ainda respira!

Não estamos frente a um contrassenso?

Ao nascituro, com toda a justiça, reconhecemos o direito à vida, que deverá ser digna, com todos os seus consectários. À pessoa, ao final doloroso de sua existência, destinamos uma vida sem vida, uma vida como obrigação de viver, uma vida indigna, uma vida que nega o fundamento constitucional da dignidade da pessoa humana e, consequentemente, a uma morte igualmente indigna.

\section{1 - A OBRIGAÇÃO DE VIVER A QUALQUER CUSTO}

Voltando às observações de JONAS, apresentadas no início desse capítulo, estendemos nossos comentários quanto à ideia de morte na concepção primitiva, em que a morte sendo o não-natural, necessita ser interpretada para ser compreendida, já que a vida disso não precisa. E tal interpretação somente pode ser praticada em favor da vida, "a única coisa que somos capazes de compreender". ${ }^{7}$ A morte pode ser negada, mas como

${ }^{7}$ JONAS, H. O Princípio Vida. Petrópolis: Vozes, 2004, p. 19. 
vida, ou seja, como transformação da vida e como tal não será buscada, já que a ela chegar-se-á naturalmente. Tal raciocínio igualmente povoa os argumentos contrários à adjetivação da vida.

Importante lembrar que nem sempre a morte apresentou-se como a inimiga a ser vencida, de todas as formas e por todos os meios, como ainda a entendemos nos dias atuais. MARREIRO menciona que, estudiosos da história da morte referem que, até o início do século XIX, era a morte "uma cerimônia pública que ocorria geralmente no âmbito doméstico, em que o próprio moribundo conhecia seu protocolo e, na maioria das vezes, chegava a presidi-lo". ${ }^{8}$ Entretanto, já no decorrer desse século XIX, com as primeiras descobertas científicas, passa a morte a ser entendida como algo a ser evitado ou mesmo negado, fonte de sentimentos vergonhosos, em que o próprio paciente escondia seu estado ou, quando dele não tinha conhecimento, era mantido na ignorância pelos seus familiares e amigos.

Com o avançar do século XX, quando as infecções, as grandes causadoras de morte, começam a ser vencidas pelo uso dos antimicrobianos, tomam o seu lugar as doenças crônicas e degenerativas, que, frente aos conhecimentos científicos cada vez mais desenvolvidos, passam a ser tratadas com bons resultados, permitindo, assim, o aumento progressivo da vida média dos povos no Ocidente.

Passa, então, a morte "a ser encarada como resultado acidental, como parte dissociada da vida". Em assim sendo, tratando-se a vida e a morte como fenômenos estanques, numa clara negação de seu íntimo relacionamento, ao lado de aparelhos mais e mais sofisticados, procedimentos invasivos e disposição médica obstinada de vencer a morte sempre, e sempre, temos os últimos dias de pacientes, muitas vezes já desenganados, deslocados para o ambiente hospitalar, nos leitos frios de uma UTI, completamente apartados de seus familiares. ${ }^{9}$

Medicam-se cada vez mais os exames, principalmente os de imagem, enquanto o paciente, de figura principal passa a detalhe, pois o importante é que tudo esteja equilibrado, os sinais vitais mantidos, mesmo que mais nenhum resultado para o sofrer dessa pessoa humana possa ser observado, como se a morte pudesse deixar de existir e o homem se tornar um deus.

${ }^{8}$ MARREIRO, C.L. Responsabilidade Civil do Médico na Prática da Distanásia. Bioética. Brasília: CFM, 2013. v.21(2), p. 312.

${ }^{9}$ Ibidem. 
Esse paciente, qualificado como terminal, corresponde àquele que não mais apresenta qualquer tipo de resposta a procedimentos destinados a devolver-lhe o estado anterior à doença que lhe acomete, ou mesmo próximo a ele. Eis que, nesse estágio de sua evolução mórbida, a morte se lhe afigura muito próxima, inevitável e previsível. Meios de tratamento heroicos e, na maior parte das vezes, extremamente dolorosos e consuntivos, apenas postergam o processo de morrer.

Tal situação constitui o que se conhece sob o termo de distanásia, em que o paciente somente atende aos desejos de uma ciência médica "técnica", num trabalho médico sem sentido, cujo resultado nada mais é que o de "anular o caráter humano do paciente: é, simplesmente, coisificá-lo". ${ }^{10}$

O atual Código de Ética Médica preocupa-se objetivamente com essa verdadeira obstinação terapêutica e assim dispõe, no Capítulo I, inciso VI, verbis:

VI - O médico guardará absoluto respeito pelo ser humano e atuará sempre em seu benefício. Jamais utilizará seus conhecimentos para causar sofrimento físico ou moral, para o extermínio do ser humano ou para permitir ou acobertar tentativa contra sua dignidade e integridade.

Mais ainda, o Conselho Federal de Medicina, na Resolução 1805, de 28 de novembro de 2006, (anexo 2) tornada válida pela 14a Vara da Justiça Federal, sediada em Brasília, em 1ํo de dezembro de 2010, após uma luta judicial por mais de três anos, estabelece que, verbis:

Art. $1^{\circ}$ : É permitido ao médico limitar ou suspender procedimentos e tratamentos que prolonguem a vida do doente em fase terminal, de enfermidade grave e incurável, respeitada a vontade da pessoa ou de seu representante legal.

${ }^{10}$ MARREIRO, C.L. Responsabilidade Civil do Médico na Prática da Distanásia. Bioética. Brasília: CFM, 2013. v.21(2), p. 313. 
A citada Resolução sublinha a obrigação do médico em esclarecer ao paciente, ou a seu representante legal, todas as informações pertinentes aos métodos terapêuticos adequados ao seu caso, fundamentar e registrar no prontuário médico a decisão tomada por aqueles, assegurandolhes os direitos a uma segunda opinião médica.

Cuida ainda a mesma Resolução, em seu dispositivo $2^{\circ}$, da atenção aos cuidados paliativos indispensáveis ao paciente nessa fase terminal de sua doença, provendo-lhe o "conforto físico, psíquico, social e espiritual, Inclusive assegurando-lhe o direito de alta hospitalar."

No que tange à ultima parte deste dispositivo, o direito à alta hospitalar, citamos a Lei 10.241, de 17 de março de 1999, do Estado de São Paulo (chamada por alguns de Lei Mario Covas), que, na mesma linha da citada Resolução do Conselho Federal de Medicina, em seu art. 2º inciso XXIV, dispõe, verbis: "São direitos dos usuários dos serviços de saúde no Estado de S. Paulo: XXIV- optar pelo local de morte".

Ambos, a Resolução e a Lei Estadual, dispõem sobre a ortotanásia, condição que não se confunde com a eutanásia. Esta, busca como resultado promover a morte, seja na forma ativa, com uma conduta comissiva visando a cessação dos sofrimentos, seja na forma passiva, quando trata-se do mesmo objetivo, desta vez com uma conduta omissiva. Tem-se ainda a chamada eutanásia de duplo feito, em que a morte é efeito indireto da conduta, quando a dose do medicamento utilizado com "o fito de dar conforto ao paciente termina por apressar-lhe a morte, embora a intenção fosse apenas minorar o sofrimento". ${ }^{11}$

A ortotanásia, na Exposição de Motivos, p.2, da referida Resolução do Conselho Federal de Medicina, define-se como a

...decisão de renunciar ao chamado excesso terapêutico (...) porque não proporcionais aos resultados que se poderiam esperar ou ainda porque demasiado gravosas para ele [paciente] e para sua família. Nestas situações, quando a morte se anuncia iminente e inevitável, pode-se em consciência

11 VILLAS-BÔAS, M.E. A Ortotanásia e o Direito Penal Brasileiro. Bioética. Brasília: CFM, 2008. v.16(1), p. 65. 
renunciar a tratamentos que dariam somente um prolongamento precário e penoso da vida.

Citando VILLA-BÔAS, verbis: “...pode-se dizer que a eutanásia é a morte antes de seu tempo, a distanásia é, por sua vez, a morte depois do tempo; e a ambas se contrapõe a ortotanásia: a morte no tempo certo". ${ }^{12}$

Portanto, o direito à vida digna implica no reconhecimento de que não há obrigação de sobrevida além do período natural, que o fundamental é tratar o paciente e não a doença, que o estar à disposição do médico os mais avançados recursos terapêuticos, não o faz obrigado a utilizá-los, se não há mais benefícios a obter, que aceitar a morte desse paciente terminal é parte de sua função como médico, que negar a dignidade a esse paciente, submetendo-o a tratamentos dolorosos e ineficazes, é levá-lo à perda de sua autoestima, o que poderá lhe acarretar desprezo e aversão por si próprio e, mais ainda, é subtrair-lhe o direito a uma morte digna.

\subsection{ATO FINAL DA VIDA: A MORTE DIGNA E A DIGNIDADE DA PESSOA HUMANA}

O entendimento do que seja morte digna está intimamente relacionado ao princípio da dignidade da pessoa humana, o segundo Fundamento da Constituição da República do Brasil. Contudo, tal princípio, que se espraia em todas as relações jurídicas observadas em nosso ordenamento jurídico, não é um conceito vago destinado a enfeitar os textos jurídicos ou a satisfazer as citações dos iniciados, permitindo a sensação de que é algo a ser olhado, mas não a ser visto, a ser apreciado, mas não a ser verdadeiramente compreendido.

A dignidade da pessoa humana "...é o valor máximo da ordem jurídica brasileira. É o centro de gravidade ao derredor do qual se posicionaram todas as normas jurídicas". ${ }^{13}$ Dessa forma, possui um chamado núcleo duro, que compreende as noções básicas de respeito às integridades

\footnotetext{
12 VILLAS-BÔAS, M.E. A Ortotanásia e o Direito Penal Brasileiro. Bioética. Brasília: CFM, 2008. v.16(1), p. 66.

${ }^{13}$ FARIAS, C.C. de \& ROSENVALD, N. Curso de Direito Civil: Contratos. $5^{\text {a }}$ ed. São Paulo: Atlas, 2015, v.4, p. 128.
} 
física e psíquica das pessoas, à liberdade e à igualdade, bem assim ao reconhecimento do direito ao mínimo existencial, mínimo esse que lhe permita viver de forma digna. Dessa feita, percebe-se que nossa Lei Maior ao reconhecer o direito à vida, adjetiva essa vida, tornando-a completa ao entendê-la, sim, como vida, mas como vida digna!

Ao olharmos pela janela da dignidade da pessoa humana, podemos ver e entender como estão posicionados os direitos da personalidade $\mathrm{e}$, especificamente, no que tange ao direito à vida digna, vislumbramos o seu corolário, na mais das vezes esquecido, tanto o evitamos, ou seja, a morte digna!

Se nos preocupamos diuturnamente com o direito à vida, que terá que ser digna, não podemos olvidar o direito à morte digna, momento esse em que mais que nunca se apresenta o princípio da dignidade da pessoa humana. Se não, vejamos: não é nos momentos finais de nossa existência, mormente se somos vítimas de doença em estágio terminal, ou se esta mesma existência se esgota pelo tempo longo já decorrido do viver, que mais dependemos que nos seja reconhecido os direitos a nossa integridade física e psíquica e que, infelizmente, é quando temos nossa vontade obliterada pela ideia de que somos incompetentes para tomar nossas próprias decisões? ${ }^{14}$

Não é também nesses mesmos momentos em que nos é tirada a liberdade de desejar cuidados e atenções diversas das que se acreditam ser as corretamente indicadas para nós? E a igualdade, esta então nem se fala: não nos tornamos diferentes dos demais, com a alegação que estamos fechando o ciclo da vida e voltamos a ser absolutamente incapazes e, portanto, claramente dependentes? ${ }^{15}$

Temos nesses momentos o direito a um mínimo existencial, ou já não somos mais donos de nossos atos e, dessa feita, não precisamos de que haja muita atenção às coisas de que precisamos, mesmo que não seja nada

\footnotetext{
${ }^{14}$ GOUVEIA, L.R. Diretivas Antecipadas de Vontade: um contrato de vida digna. 2013. 49 fls. Trabalho de Conclusão de Curso de Pós-Graduação lato sensu em Direito Civil Geral, Universidade Anhanguera-Uniderp, Rio de Janeiro, RJ, p. 21. ${ }^{15}$ Ibidem.
} 
mais que um conforto físico e psíquico, representado por um ambiente tranquilo e acolhedor? ${ }^{16}$

Todos vamos morrer e esta é a única certeza em nossa existência, mas será que precisamos morrer impotentes quanto a decisões sobre nós mesmos, olvidados quanto a nossos desejos, desamparados quanto a nossas necessidades? ${ }^{17}$

Será que precisamos obrigatoriamente terminar nossa existência verdadeiramente agarrados a tubos de ventilação e de infusões, em meio ao barulho insuportável da parafernália de uma UTI e dos lamentos contínuos de outros como nós, sofrendo com as contínuas e perenes agulhadas de medicamentos que nos depauperam e sepultam nossas poucas esperanças de convivência com nossos entes queridos? ${ }^{18}$

Ora, a vida digna, ao encontrar o seu fim, necessariamente o encontrará de forma digna, ou seja, não terá cabimento deixar de ser digna nesses momentos finais, porquanto, a morte, que significa o terminar da vida digna, obviamente será também digna!

E o que é uma morte digna? Voltemos ao princípio da dignidade da pessoa humana, porque enquanto não cessa a vida digna, enquanto seus momentos finais não se apresentam, estamos frente a uma pessoa humana, ainda viva, embora no portal da morte, sendo esse a passagem final. Observa-se que esse portal, essa passagem final. é uma continuação da vida em seus estertores, por isso ainda é prenhe de dignidade, logo, a morte que aí se inicia é, por força do próprio momento, uma morte digna, pois uma vida digna se acompanha naturalmente de uma morte digna. Estão ambas indissoluvelmente ligadas!

A conclusão natural de tal raciocínio é de que uma morte digna também se encontra sob o pálio do princípio da dignidade da pessoa humana, auferindo a pessoa os benefícios do respeito as suas integridades física e psíquica, a sua liberdade, a sua igualdade e ao seu direito ao mínimo existencial. E como se dá o cumprimento desses benefícios nesses momentos? Ao entender-se que a vida é digna até o seu final, o momento desse

${ }^{16}$ GOUVEIA, L.R. Diretivas Antecipadas de Vontade: um contrato de vida digna. 2013. 49 fls. Trabalho de Conclusão de Curso de Pós-Graduação lato sensu em Direito Civil Geral, Universidade Anhanguera-Uniderp, Rio de Janeiro, RJ, p. 21.

${ }^{17}$ Ibidem.

${ }^{18}$ Ibidem. 
final será, no desenvolver dessa existência humana, decidido durante a vida, quando a pessoa, detentora de completo discernimento sobre seus atos, plenamente informada sobre sua situação, pode decidir que quer manter sua integridade física e psíquica, por não desejar mais tratamentos que impossibilitem sua livre fruição; pode decidir terminar seus dias em casa com sua família e amigos, desfrutando da liberdade e igualdade no trato familiar a que tem direito e, bem assim, pode decidir usufruir do conforto e da alegria que essa vida lhe irá certamente proporcionar.

Essa pessoa ainda está viva e consciente, preparando-se para a eterna viagem, até seus momentos finais, porque como pessoa humana está sob a proteção do princípio da dignidade da pessoa humana até que deixe de existir como pessoa. Esta é a morte digna!

Entretanto, para que se pudesse chegar a tal compreensão da existência humana, como algo que deve ser voltado para a realização da pessoa, a que tem o direito a encontrar, expressos, no texto constitucional, os seus direitos fundamentais, alicerçados pelo princípio da dignidade da pessoa humana, inúmeros percalços foram observados com o passar do tempo, em um processo evolutivo, por vezes extremamente dolorido.

Para que analisemos essa evolução, embora de forma bastante resumida, precisamos analisar como se desenvolveu o pensar médico e o pensar da sociedade, frente ao desenvolvimento quase inebriante da tecnologia médico-científica. Quais foram os pensamentos que acompanharam essa evolução, dela surgindo e a ela influenciando. Eis que estamos falando da Bioética.

\subsection{ATO FINAL DA VIDA: A MORTE DIGNA E A BIOÉTICA}

Em trabalho nosso anterior (GOUVEIA, 2007, p. 34), estudamos o surgimento do termo Bioética, como apresentado por ALMEIDA (1999, p.5), em sua tese de Doutorado, ao consultar o artigo "Bioethics, the science of survival", de autoria do oncologista e biólogo norte-americano Van Rensselaer Potter, da Universidade de Wisconsin e que publica no ano seguinte a obra "Bioethics: bridge to the future". Preocupou-se o estudioso, frente aos vertiginosos avanços da tecnociência biomédica, com o respeito à dignidade da pessoa humana numa perspectiva ecológica, entre a ciência e a filosofia, entendendo a Bioética como um novo ramo da ciência, na citação de SAUWEN (2000, p.18), uma "ciência da sobrevivência". Tal se 
deu porque Potter, como oncologista que era, havia estabelecido as relações entre as modificações causadas, pelos avanços tecnológicos, ao meio ambiente e o surgimento de certos tipos de cânceres. ${ }^{19}$

Hellegers, obstetra, fisiologista fetal e demógrafo, da Universidade de Georgetown, em Washington, utilizou o novo termo com um sentido diverso, ou seja, ele situou a bioética no campo da filosofia, aplicada esta às novas situações surgidas na área biomédica, socorrendo-se, para tal, de princípios éticos normativos em vez de ferramentas científicas. ${ }^{20}$ Tal posição deveu-se à sua formação multidisciplinar, "diferentemente de Potter, que permanecia com a visão dicotomizada, advinda do século anterior, em que se situavam em campos diversos a ciência e a filosofia". ${ }^{21}$

Modificações profundas no pensamento humano, quanto ao poder cada vez maior da medicina, e do médico, e a consciência crescente da pessoa no que concerne a sua compreensão como indivíduo, principalmente no aspecto de sua autodeterminação na assistência médica, foram as bases da implantação desses novos conceitos. Um melhor conhecimento acerca do trabalho médico e da relação médico paciente; um sentimento de necessidade de reforma dos costumes e dos valores sociais; e, principalmente, certos acontecimentos relacionados à pesquisa e assistência médica de massa, foram os fatores que contribuíram de forma incisiva para o surgimento da Bioética. ${ }^{22}$

${ }^{19}$ GOUVEIA, L.R. Diretivas Antecipadas de Vontade: um contrato de vida digna. 2013. 49 fls. Trabalho de Conclusão de Curso de Pós-Graduação lato sensu em Direito Civil Geral, Universidade Anhanguera-Uniderp, Rio de Janeiro, RJ, p. 34.

${ }^{20}$ ALMEIDA, José Luiz Telles de. Respeito à Autonomia do Paciente e Consentimento Livre e Esclarecido: uma abordagem principialista da relação médico-paciente. Cap. 2, Tese de Doutorado, Fundação Oswaldo Cruz, Escola Nacional de Saúde Pública: Rio de Janeiro, 1999. Disponível em http://portalteses.cict.fiocruz.br. Acesso em: 11 de maio de 2006, p. 7.

${ }^{21}$ GOUVEIA, L.R. Diretivas Antecipadas de Vontade: um contrato de vida digna. 2013. 49 fls. Trabalho de Conclusão de Curso de Pós-Graduação lato sensu em Direito Civil Geral, Universidade Anhanguera-Uniderp, Rio de Janeiro, RJ, p. 34.

${ }^{22}$ ALMEIDA, José Luiz Telles de. Respeito à Autonomia do Paciente e Consentimento Livre e Esclarecido: uma abordagem principialista da relação médico-paciente. Cap. 2, Tese de Doutorado, Fundação Oswaldo Cruz, Escola Nacional de Saúde Pública: Rio de Janeiro, 1999. Disponível em http://portalteses.cict.fiocruz.br. Acesso em: 11 de maio de 2006, p. 7. 
Acontecimentos significativos no final dos anos 60 e início dos 70, no século próximo passado, impulsionaram sobremaneira o desenvolvimento desse novo campo do conhecimento humano. Um deles envolvia os critérios de escolha de pacientes que poderiam submeter-se à hemodiálise, momento em que, devido à pressão social, incluiu-se os que viviam à margem da sociedade, como os desempregados, e retirou-se as prioridades conferidas, primeiramente aos homens em prejuízo das mulheres e dos casados em prejuízo dos solteiros, criando-se um programa governamental em que todos tinham o mesmo direito ao tratamento dialítico. ${ }^{23}$

ALMEIDA, ainda em sua Tese, refere pesquisas científicas em seres humanos, pesquisas essas realizadas ao arrepio das condições éticas estabelecidas no pós-guerra, com o Código de Nuremberg, como o desenvolvimento de uma vacina para a hepatite B em 800 crianças deficientes mentais em Staten Island, no Estado de Nova York e a injeção de células cancerosas em 22 pacientes idosos e senis, sem que lhes fosse informado de seu conteúdo, na cidade de Nova York. ${ }^{24}$

Encontramos, nessas situações de completo desrespeito a seres humanos, uma sociedade embevecida pelo desenvolvimento vertiginoso da tecnologia médico-científica, onde observa-se a transformação do paciente, de completo incapaz na compreensão e atuação em sua própria doença e tratamento, em um verdadeiro receptáculo de novas técnicas e de novos medicamentos, alijado até mesmo do conhecimento de quem seja o seu médico-assistente, visto o quase que completo isolamento entre eles, passando a ser entendido, não mais como o sofredor de uma doença, mas sim como o portador dela. ${ }^{25}$

${ }^{23}$ GOUVEIA, L.R. Diretivas Antecipadas de Vontade: um contrato de vida digna. 2013. 49 fls. Trabalho de Conclusão de Curso de Pós-Graduação lato sensu em Direito Civil Geral, Universidade Anhanguera-Uniderp, Rio de Janeiro, RJ, p. 35.

${ }^{24}$ ALMEIDA, José Luiz Telles de. Respeito à Autonomia do Paciente e Consentimento Livre e Esclarecido: uma abordagem principialista da relação médico-paciente. Cap. 2, Tese de Doutorado, Fundação Oswaldo Cruz, Escola Nacional de Saúde Pública: Rio de Janeiro, 1999. Disponível em http://portalteses.cict.fiocruz.br. Acesso em: 11 de maio de 2006, p. 7.

${ }^{25}$ GOUVEIA, L.R. Diretivas Antecipadas de Vontade: um contrato de vida digna. 2013. 49 fls. Trabalho de Conclusão de Curso de Pós-Graduação lato sensu em Direito Civil Geral, Universidade Anhanguera-Uniderp, Rio de Janeiro, RJ, p. 36. 
Igualmente de acentuada importância, encontramos os movimentos sociais característicos da década de 60 , como os voltados para os direitos civis em favor das minorias étnicas e o do acesso maior da sociedade à informação, que criam um ambiente altamente propício para o desenvolver e o consolidar desse novo campo do conhecimento humano, a Bioética.

Ambiente esse que, "fervilhante de novos costumes e de novos valores históricos, culturais e científicos, permitia, ao contrário do que acontecia até então, a presença de profissionais e estudiosos não médicos, em um campo notoriamente território exclusivo do profissional da Medicina. Era o casamento da ética médica com a filosofia, mas que somente começou a atingir o fim a que propunha, ou seja, o de trazer respostas mais imediatas aos dilemas ético-morais que ora se apresentavam, quando se criou um modelo principiológico da Bioética, o que se materializou na conhecida obra de BEAUCHAMP; CHILDRESS: Principles of Biomedical Ethics, em 1977 (2001)". ${ }^{26}$

\subsection{ATO FINAL DA VIDA: O PRINCÍPIO DA AUTONOMIA DO PACIENTE}

Primeiramente deve-se lembrar que Bioética, "área de reflexão, discussão e interação entre pessoas interessadas em discutir e estabelecer hierarquias de valores" ${ }^{27}$, não é o mesmo que deontologia ou ética médica. Enquanto a primeira cuida das chamadas éticas profissionais, ou seja, compreende normas - direitos e deveres - a serem cumpridos por determinada categoria profissional, acompanhadas das respectivas sanções, a ética médica prende-se a uma teorização sobre os valores morais, a uma análise crítica dos costumes e "à indicação dos pressupostos necessários para que um determinado ato humano possa ser inserido no âmbito da moralidade."que investiga, nas áreas da ciência da vida e da saúde, a totalidade

${ }^{26}$ ALMEIDA apud GOUVEIA, L.R. Diretivas Antecipadas de Vontade: um contrato de vida digna. 2013. 49 fls. Trabalho de Conclusão de Curso de PósGraduação lato sensu em Direito Civil Geral, Universidade Anhanguera-Uniderp, Rio de Janeiro, RJ, p. 36.

${ }^{27}$ SEGRE, Marco. Ensino da Bioética lato sensu. In: Bioética. Vol. 11, n. 2. Brasília: CFM, 2003, p. 57. 
das condições necessárias a uma administração responsável da vida humana em geral e da pessoa humana em particular". ${ }^{28}$

O modelo principiológico de Bioética de BEAUCHAMP; CHILDRESS, assim conhecido, referido no Capítulo anterior desse nosso trabalho, é "expresso por um conjunto de princípios éticos gerais, prima facie, ou seja, princípios não absolutos, contextualizados e sem nenhuma hierarquia estabelecida a priori, a ser adaptado aos casos concretos que se apresentem na lide diária do profissional. Isto porque, em um mundo como este em que vivemos, em constante transformação, os conceitos de justiça, verdade e moralidade pisam em terreno movediço, mudando de significado conforme novas técnicas e novos saberes se desenvolvem, o que limita de muito a aplicação de teorias éticas, que refletem fundamentos definitivos e não flexíveis". ${ }^{29}$

Os princípios que compunham o modelo em pauta eram: o da Beneficência - fazer sempre o melhor para o outro - e o da Não-Maleficência - não causar mal ou dano a outrem. A esses princípios, os estudiosos acrescentaram dois outros: o da Justiça - não tratar uma pessoa diferentemente das demais, atendendo-se à ideia de equidade e mérito - e o da Autonomia - a autodeterminação do indivíduo, aplicada à assistência médica - este de importância fundamental em nosso estudo. ${ }^{30}$

Autonomia está intimamente relacionada às ideias de indivíduo e de liberdade de pensamento, significando a autonomia do paciente aquela em que este tem o poder de "decidir sobre que profissional consultar e a quais tratamentos se submeter". ${ }^{31}$

A Declaração Universal sobre Bioética e Direitos Humanos da Organização das Nações Unidas para a Educação, a Ciência e a Cultura

${ }^{28}$ SAUWEN, R.F. ; HRYNIEWICZ, S. O Direito "in vitro": Da Bioética ao Biodireito. 2ed. Rio de Janeiro: Lumen Juris, 2000, p. 21.

${ }^{29}$ GOUVEIA, L.R. Diretivas Antecipadas de Vontade: um contrato de vida digna. 2013. 49 fls. Trabalho de Conclusão de Curso de Pós-Graduação lato sensu em Direito Civil Geral, Universidade Anhanguera-Uniderp, Rio de Janeiro, RJ, p. 38.

${ }^{30}$ GOUVEIA, L.R. Diretivas Antecipadas de Vontade: um contrato de vida digna. 2013. 49 fls. Trabalho de Conclusão de Curso de Pós-Graduação lato sensu em Direito Civil Geral, Universidade Anhanguera-Uniderp, Rio de Janeiro, RJ, p. 41-44.

31 KOVÁCS, M.J. Pesquisa com Pacientes Gravemente Enfermos: autonomia, riscos, benefícios e dignidade. Bioética. Brasília: CFM, 2009. v.17(2)., p. 310. 
(UNESCO), em sua homologação, apresenta a autonomia disposta nos seguintes artigos: "autonomia e responsabilidade individual (art.5ำ), consentimento (art.6º ) e indivíduos incapazes de consentir (art.7oㅡ". A autonomia apresenta-se agora ampliada no contexto acadêmico internacional. ${ }^{32}$

Interessante anotar que esta autonomia, em que o paciente exercita o poder de tomar decisões sobre o tratamento que lhe é proposto, encontra acentuada aceitação nos Estados Unidos da América, ao contrário da Europa, onde a prática vigente, na maioria dos países, ainda é bastante paternalista, devido a diferenças culturais, em que "os doentes não são informados integralmente sobre a sua situação de saúde, especialmente nos casos de doença grave que conduz a morte em curto prazo". ${ }^{33}$

Claro está que a pessoa, além de estar completamente informada, em linguagem afeita à sua compreensão, sobre a gravidade de sua doença e, igualmente, no que tange aos detalhes que lhes irão afetar o corpo e a mente ao se submeter ao tratamento indicado, bem assim aos riscos que correrá e aos benefícios que poderá auferir, deverá obrigatoriamente estar em plenas condições mentais para decidir, de forma segura, qual o caminho que deseja seguir. ${ }^{34}$

Dessa forma, percebe-se que o dever de informação, pedra de toque do relacionamento médico-paciente, deverá ser exercido em sua plenitude, permitindo-se ao paciente, e a seus familiares, a real compreensão de seu estado e as possibilidades e consequências que poderão advir da decisão tomada. ${ }^{35}$

O exercício da autonomia do paciente está estreitamente relacionado à sua competência, ou seja, à sua capacidade de efetivo entendimento

32 ALBUQUERQUE, R.; GARRAFA, V. Autonomia e Indivíduos sem a Capacidade para Consentir: o caso dos menores de idade. Bioética. Brasília: CFM, 2016, 24(3), p. 453.

${ }^{33}$ OLIVEIRA, M.Z.P.B.; BARBAS, Stela. Autonomia do Idoso e Distanásia. Bioética. Brasília: CFM, 2013. v.21(2), p. 332.

${ }^{34}$ GOUVEIA, L.R. Diretivas Antecipadas de Vontade: um contrato de vida digna. 2013. 49 fls. Trabalho de Conclusão de Curso de Pós-Graduação lato sensu em Direito Civil Geral, Universidade Anhanguera-Uniderp, Rio de Janeiro, RJ, p. 20.

${ }^{35}$ GOUVEIA, L.R. Diretivas Antecipadas de Vontade: um contrato de vida digna. 2013. 49 fls. Trabalho de Conclusão de Curso de Pós-Graduação lato sensu em Direito Civil Geral, Universidade Anhanguera-Uniderp, Rio de Janeiro, RJ, p. 20. 
do que está sendo informado pelo médico, lembrando que cada decisão desse paciente deverá ser restrita ao momento em questão, não devendo ser estendida automaticamente às várias decisões posteriores. Não se trata de uma carta de alforria, mas de permissão temporária e motivada, que deverá ser renovada a cada nova alternativa terapêutica. ${ }^{36}$

Mais ainda, devemo-nos lembrar de que "Não é comum questionar a competência da decisão do paciente quando sua decisão está de acordo com a do médico", como assinalam OLIVEIRA; BARBAS. ${ }^{37} \mathrm{Em}$ caso de desacordo, será, certamente, o momento de sugerir uma outra opinião médica, comportamento que faz parte dos direitos dos pacientes e que demonstra a segurança do médico na condução do tratamento daquele determinado paciente. ${ }^{38}$

Estudo interessantíssimo ${ }^{39}$ sobre a autonomia do idoso revela que $67 \%$ deles, de um total de 112 (cento e doze), com idades entre 60 e 80 anos ou mais, não eram favoráveis à manutenção da vida "de qualquer jeito". Para tal alegaram ser necessário algum "indicador de qualidade de vida", como lucidez (79\%), respirar sem o uso de aparelhos (17\%) e comer sem o auxílio de sonda (4\%). Significativo é o fato de que lucidez foi a razão, de longe, a mais importante para esses pacientes. Deve-se notar que os 33\% restantes, que eram favoráveis, apresentaram respostas como "enquanto há vida há esperança", só Deus pode tirar a vida de alguém"e "os aparelhos (recursos tecnológicos) existem para serem usados", o que possivelmente aponta para a dificuldade de se sentir em estágio terminal, ou mesmo, como alguns declararam, o fato de não dispor de familiares para

${ }^{36}$ GOUVEIA, L.R. Diretivas Antecipadas de Vontade: um contrato de vida digna. 2013. 49 fls. Trabalho de Conclusão de Curso de Pós-Graduação lato sensu em Direito Civil Geral, Universidade Anhanguera-Uniderp, Rio de Janeiro, RJ, p. 20.

37 OLIVEIRA, M.Z.P.B.; BARBAS, Stela. Autonomia do Idoso e Distanásia. Bioética. Brasília: CFM, 2013. v.21(2), p. 239.

${ }^{38}$ GOUVEIA, L.R. Diretivas Antecipadas de Vontade: um contrato de vida digna. 2013. 49 fls. Trabalho de Conclusão de Curso de Pós-Graduação lato sensu em Direito Civil Geral, Universidade Anhanguera-Uniderp, Rio de Janeiro, RJ, p. 21.

${ }^{39}$ OLIVEIRA, M.Z.P.B.; BARBAS, Stela. Autonomia do Idoso e Distanásia. Bioética. Brasília: CFM, 2013. v.21(2), p. 332. 
os cuidados em residência, ou, ainda, falta de recursos para a compra de medicamentos. ${ }^{40}$

Igualmente digno de nota para os $67 \%$, que não eram favoráveis à manutenção da vida a qualquer custo, é o fato de que terminar a vida em casa com seus familiares seria "coisa natural", já que poderiam despedirse dos amigos, receber carinhos dos seus, pedir perdão e perdoar, prepararse segundo suas crenças religiosas, utilizar tratamentos caseiros, como chás, caldos, compressas, etc. e, significativamente, "decidir sobre os bens". ${ }^{41}$ Representa esse último desejo a importância dada pelos pacientes ao estado de lucidez e a necessidade do respeito ao seu poder de decisão, que, sem dúvida, deverá ser estendido às demais situações enfrentadas por um paciente terminal, idoso ou não. ${ }^{42}$

No outro extremo da vida, encontramos os menores de idade sem a capacidade legal para consentir, (no ordenamento jurídico brasileiro o limite é de 16 anos de idade, quando até então o menor é absolutamente incapaz), em que a autorização para esse consentimento, realizado de maneira livre e autônoma, é repassada para seus representantes legais. Artigo recente, que trata do tema, aponta para o paternalismo como limitação para a autonomia desses pacientes, exercido, na oportunidade, não somente pelos familiares, bem assim pelos profissionais médicos que os assistem. ${ }^{43}$

Digna da nota foi a alteração legislativa realizada na Bélgica, em 2014, conforme anotam esses autores, "estendendo para as crianças o direito de solicitar a eutanásia em casos de doenças terminais e removendo qualquer referência a restrições de idade. São previstas condições de consciência da criança e a presença de sofrimentos insuportáveis e sem alívio,

${ }^{40}$ GOUVEIA, L.R. Diretivas Antecipadas de Vontade: um contrato de vida digna. 2013. 49 fls. Trabalho de Conclusão de Curso de Pós-Graduação lato sensu em Direito Civil Geral, Universidade Anhanguera-Uniderp, Rio de Janeiro, RJ, p. 22.

${ }^{41}$ OLIVEIRA, M.Z.P.B.; BARBAS, Stela. Autonomia do Idoso e Distanásia. Bioética. Brasília: CFM, 2013. v.21(2), p. 333.

${ }^{42}$ GOUVEIA, L.R. Diretivas Antecipadas de Vontade: um contrato de vida digna. 2013. 49 fls. Trabalho de Conclusão de Curso de Pós-Graduação lato sensu em Direito Civil Geral, Universidade Anhanguera-Uniderp, Rio de Janeiro, RJ, p. 22.

43 ALBUQUERQUE, R.; GARRAFA, V. Autonomia e Indivíduos sem a Capacidade para Consentir: o caso dos menores de idade. Bioética. Brasília: CFM, 2016, 24(3), p. 452. 
condições essas avaliadas por psiquiatra infantil ou psicólogo, "bem como o apoio da decisão por um dos pais, ou responsáveis legais", o que trará respaldo aos envolvidos, caracterizando uma solução pertinente. ${ }^{44}$

Os autores evidenciam que os profissionais médicos, embora ajam visando o benefício das crianças, o fazem, em realidade, dentro de suas próprias convicções. Mais ainda, que o paternalismo, que, de resto também encontra guarida no tratamento de todo e qualquer paciente, no caso das crianças pode igualmente ser visto como um “...mecanismo de proteção dos profissionais e pesquisadores, para isentá-los de responsabilidades judiciais". ${ }^{45}$

Tal realidade demanda, segundo ainda os autores, a criação de dispositivos legais, que amparem as decisões dos menores sobre os meios de tratamento a que sejam submetidos, respeitando sua autonomia, de forma que sua aceitação pelos médicos, e mesmo pelos familiares, não represente ameaças que possam lhes dificultar o respeito a tais decisões.

Opinam ainda os autores que, enquanto não existam os referidos dispositivos, tal papel seria de competência de "equipes multidisciplinares de saúde e que formam os comitês de bioética clínica e/ou hospitalar, [que] parecem ser a melhor alternativa para garantir a autonomia e proteção desses sujeitos". ${ }^{46}$

Em suma, o direito à morte digna, aspecto não contemplado explicitamente em nosso Código Civil, mas claramente protegido pelo fundamento constitucional da dignidade da pessoa humana, como vimos no decorrer de nossa exposição, pode ser expresso pelo respeito às seguintes situações, muito bem apresentadas por OLIVEIRA, verbis:

...direito de conhecer a realidade de sua situação, (...)direito de decidir sobre tratamento em colaboração com os profissionais da saúde (...),

44 ALBUQUERQUE, R.; GARRAFA, V. Autonomia e Indivíduos sem a Capacidade para Consentir: o caso dos menores de idade. Bioética. Brasília: CFM, 2016, 24(3), p. 457.

45 ALBUQUERQUE, R.; GARRAFA, V. Autonomia e Indivíduos sem a Capacidade para Consentir: o caso dos menores de idade. Bioética. Brasília: CFM, 2016, 24(3), p. 452.

${ }^{46}$ ALBUQUERQUE, R.; GARRAFA, V. Autonomia e Indivíduos sem a Capacidade para Consentir: o caso dos menores de idade. Bioética. Brasília: CFM, 2016, 24(3), p. 452. 
respeito pela vontade de não ser abandonado pela família,pelos amigos, por seu médico predileto, pelo direito a tratamento paliativo para amenizar seu sofrimento e sua dor e não ser tratado como mero objeto, cuja vida pode ser encurtada ou prolongada segundo as conveniências da família ou da equipe médica. ${ }^{47}$ (grifo nosso)

Eis que, face à necessidade, cada vez mais presente, do respeito à autonomia do paciente terminal, seja motivada por doença, seja pelo exaurimento provocado pela idade avançada, surge uma luz no fim do túnel, representada pela Resolução 1995/2012, do Conselho Federal de Medicina, intitulada Diretivas Antecipadas de Vontade, assunto tratado a seguir.

\subsection{DIRETIVAS ANTECIPADAS DE VONTADE: RESOLUÇÃO 1995, CFM, 31/08/ 2012}

Na Resolução 1995/2012, do Conselho Federal de Medicina, em seu art. 1ํㅗ são definidas as Diretivas Antecipadas de Vontade dos pacientes, Testamento Vital no meio jurídico, como"...o conjunto de desejos, prévia e expressamente manifestados pelo paciente, sobre cuidados e tratamentos que quer, ou não, receber no momento em que estiver incapacitado de expressar, livre e autonomamente, sua vontade".

Complementando, dispõe a Resolução, no caput do art. $2^{\circ}$, que, verbis: "Nas decisões sobre cuidados e tratamentos de pacientes que se encontram incapazes de comunicar-se, ou de expressar de maneira livre e independente suas vontades, o médico levará em consideração suas diretivas antecipadas de vontade".

Deve-se notar que tal ato normativo, em verdade, vem complementar a Resolução 1805, de 28 de novembro de 2006, do Conselho Federal de Medicina, tornada válida pela 14a Vara da Justiça Federal, em 1ํ de dezembro de 2010, como já mencionamos anteriormente, que regulamenta a ortotanásia, ressaltando a obrigatoriedade dos cuidados paliativos. Assim dispõe a referida Resolução, verbis:

${ }^{47}$ OLIVEIRA, M.Z.P.B.; BARBAS, Stela. Autonomia do Idoso e Distanásia. Bioética. Brasília: CFM, 2013. v.21(2), p. 91. 
Art. $1^{\circ}$ : É permitido ao médico limitar ou suspender procedimentos e tratamentos que prolonguem a vida do doente em fase terminal, de enfermidade grave e incurável, respeitada a vontade da pessoa ou de seu representante legal.

Observa-se aqui, mais uma vez, a importância de que goza a autonomia do paciente, vendo este, assim, respeitado o seu direito à morte digna, na melhor interpretação do fundamento constitucional da dignidade da pessoa humana.

Mais ainda, reforça esta citada Resolução 1805/2006, em seu artigo $2^{\circ}$, a obrigatoriedade da administração dos cuidados médicos paliativos, que não podem, em nenhuma hipótese, deixar de serem prestados, pois a não continuidade de um tratamento invasivo e inútil não significa o abandono do paciente à sua própria sorte, pelo contrário, é o momento em que mais assistência lhe será devida. Importante lembrar que tais cuidados paliativos, conforme entendimento da OMS (Organização Mundial de Saúde, 2013), representam uma forma de terapêutica destinada a melhorar a qualidade de vida desses pacientes e de seus familiares, ao estabelecer precocemente a necessidade de assistência no tratamento da dor e de outras condições mórbidas de ordem física, psicossocial e espiritual.

Não devemos olvidar que, no imaginário social, os cuidados paliativos ainda são entendidos como ausência de tratamento. Se não são ministrados medicamentos específicos, já que estes não mais representam benefícios para o paciente, uma visão terminativa do tratamento médico aflora aos sentimentos dos que cercam o paciente, notadamente familiares, que entendem a doença como o objetivo primeiro a ser atacado, no esquecimento de que esta, a doença, só existe porque existe o paciente e que este é que representa o verdadeiro foco desse tratamento. E a pessoa pode ser olhada com desalento, muitas vezes não mais recebendo a atenção de que tanto necessita. Daí a marcada importância do relacionamento cuidadoso entre os profissionais que assistem o paciente e os familiares que o acompanham, em que estes últimos devem receber as informações, as mais precisas possíveis, sobre o estado do paciente, para que possam internalizar a enorme importância da sua assistência, no desenrolar dos momentos finais de seu ente querido, assistência essa, representada, principalmente, pelo carinho e atenção, que serão de vital importância, seja no ambiente hospitalar, seja no aconchego do lar. 
Nessa linha de pensamento, é reconhecido, nesse ato normativo, o direito do paciente em desejar e em receber a alta hospitalar, para terminar seus dias no convívio de seus familiares e amigos e, vale dizer, também em seu próprio leito domiciliar. Leia-se o referido dispositivo da Resolução 1805/2006, verbis:

art. 20 - O doente continuará a receber todos os cuidados necessários para aliviar os sintomas que levam ao sofrimento, assegurada a assistência integral, o conforto físico, psíquico, social e espiritual, inclusive assegurando-lhe o direito da alta hospitalar.

Registre-se, por outro lado, o cuidado da Resolução 1995/2012, tratando das Diretivas Antecipadas de Vontade, objeto de nosso estudo, em assegurar "a obrigação do médico de esclarecer ao paciente, ou ao seu representante legal, as modalidades terapêuticas adequadas para cada situação"(art. $1^{\circ}, \S 1^{\circ}$ ), bem assim "o direito de solicitar uma segunda opinião médica."(art. 1ํㅡ $\left.\S 3^{\circ}\right)$.

Retornando ao art. 1ㅜ, observa-se um aspecto digno de nota, presente no parágrafo $2^{\circ}$, verbis: art.1ㅇ: $\$ 2^{\underline{o}}-\boldsymbol{A}$ decisão referida no caput deve ser fundamentada e registrada no prontuário. (grifo nosso)

Trata-se de regra contratual importante, em que, de mera explicitação verbal de desejos do paciente, tem-se um contrato escrito, fundamentado e registrado em documento médico. Interessante aduzir que, embora o referido artigo não o mencione, o prontuário médico é apenas um dos documentos médicos construídos num atendimento médico, desde que tal documento está presente apenas nas internações, sejam estas em hospitais ou clínicas médicas. $\mathrm{O}$ atendimento médico pode ser também realizado em consultório médico, quando o paciente, em sua consulta, acorda com seu médico-assistente a decisão de que trata a Resolução citada, sendo, então, as Diretivas Antecipadas de Vontade registradas em sua ficha médica.

Cabe aqui, a nosso ver, uma digressão a respeito do local a serem registradas as Diretivas. Observamos tratar-se de um contrato médico de conteúdo um tanto diverso dos contratos médicos em geral, já que estes são caracterizados pela atuação do profissional em diagnosticar a doença e estabelecer sua linha de tratamento, com a aquiescência do paciente, que se coloca na condição de ser ajudado na cura ou em melhoras de sua situação 
mórbida, como aponta muito bem FARIAS; ROSENVALD, verbis:”...o médico, que é contratado por um paciente para auxiliá-lo na cura de uma patologia, é quem decide a melhor maneira e a melhor técnica de atuação, com vistas à obtenção do êxito almejado". ${ }^{48}$

No caso das Diretivas Antecipadas de Vontade, o médico esclarece cuidadosamente o paciente, ou o seu representante legal, da inutilidade das medidas terapêuticas extraordinárias existentes para o caso, apontando, por via de consequência, que lhe será administrado tratamento dito conservador, também chamado paliativo. Caso o paciente não deseje permanecer aplicando tais métodos terapêuticos heroicos, ou seja, deseje não insistir em tratamento não mais exitoso, irá expor seus desejos e os terá registrados, exercendo, assim, seu direito a autonomia.

Observa-se, nesses momentos a especificidade de desse contrato, o que nos inclina para o entendimento de uma forma diversa de registro, pois nos parece estarmos frente a um outro contrato, embora entre as mesmas partes, mas com objeto diverso. Este objeto, nesse novo contrato, refere-se também a atitudes específicas relacionadas a medidas paliativas, com exclusão de outras medidas terapêuticas, que, não fora a especificidade do caso terminal, em que são consideradas inúteis, seriam as indicadas para outros pacientes em estágios diversos de evolução da mesma condição mórbida.

Embora cabendo maior exercício de reflexão, quedamo-nos inclinados a indicar a feitura do citado contrato como instrumento particular, assinado pelo médico-assistente e pelo paciente, ou seu representante legal, apensado à sua ficha médica ou ao seu prontuário, nesse último caso que tal se dê durante sua internação hospitalar.

É importante lembrar que estamos frente a uma situação nova no que se refere ao contrato Diretivas Antecipadas de Vontade, o que certamente ira suscitando uma série de novas dúvidas, posto que se trata de matéria nova, ainda não legislada em nosso país. DADALTO, em recente artigo a respeito do tema, comenta sobre algumas dessas dúvidas, verbis:

...necessidade de legislação específica sobra as diretivas antecipadas de vontade, a fim de regulamentar questões afetas ao discernimento do

${ }^{48}$ FARIAS, C.C. de \& ROSENVALD, N. Curso de Direito Civil: Parte Geral e LINDB. 13 ${ }^{a}$ ed. São Paulo: Atlas, 2015 . v.1, p. 796. 
outorgante, a uma exemplificação decuidados e tratamentos que podem ou não ser recusados, aos critérios para aceitação e recusa dos mesmos, ao registro das diretivas antecipadas e à extensão da participação do médico da feitura das diretivas. ${ }^{49}$

\subsection{UM CONTRATO DE VIDA DIGNA}

"Não se pode negar a formação de um autêntico contrato entre o cliente e o médico quando este o atende.", assim define a relação médicopaciente o eminente jurista GONÇALVES. ${ }^{50}$

Mas, o que é um contrato? FARIAS; ROSENVALD, socorrendose do conceito de Antonio Junqueira de AZEVEDO, assim o conceituam, verbis:

...todo fato jurídico consistente em declaração de vontade, a que o ordenamento jurídico atribui os efeitos designados como queridos, pelas partes, respeitados os pressupostos de existência, validade e eficácia impostos pelo sistema jurídico que sobre ele incide. ${ }^{51}$ (grifo nosso)

Mas, todo contrato, como sabido, é um negócio jurídico. Como, então, conceituaremos um negócio jurídico? Mais uma vez, buscamos o auxílio do grande AZEVEDO, que nos ensina que o negócio jurídico é, verbis:

...todo fato jurídico consistente na declaração de vontade, a que o ordenamento jurídico atribui os efeitos designados como queridos, respeitados os

${ }^{49}$ DADALTO, L. Reflexos Jurídicos da Resolução CFM 1995/2012. Bioética. Brasília: CFM, 2013. v.21(1). v.1, p. 111.

${ }^{50}$ GONÇALVES, C.R. Direito Civil Brasileiro: Responsabilidade Civil. $2^{\mathrm{a}}$ ed. ver. atual. São Paulo: Saraiva, 2007. v.4, p. 238.

${ }^{51}$ FARIAS, C.C. de \& ROSENVALD, N. Curso de Direito Civil: Contratos. $5^{\text {a }}$ ed. São Paulo: Atlas, 2015, v.4, p. 32. 
pressupostos de existência, validade e eficácia impostos pela norma jurídica que sobre ele incide. ${ }^{52}$

Nota-se, de importância, no que toca ao contrato, o acréscimo, por FARIAS; ROSENVALD, da expressão - pelas partes - objeto de grifo nosso, que vem demonstrar a diferença fundamental entre os dois institutos. Enquanto "todo o discurso do negócio jurídico (...) centra-se no declarante como único sujeito da ação, cabendo ao declaratário um papel passivo, de puro receptor", no contrato é ressaltada "a natureza bifrontal da autodeterminação (...), a sua dimensão relacional e a intersubjetividade". ${ }^{53}$

Dessa forma, tem-se que, no contrato, a declaração de vontade, composta de mais de uma manifestação de vontade, reflete um acordo, resultado de uma construção das partes, acordo esse que converge diretamente para um objetivo comum. Portanto, o que diferencia o contrato espécie, do negócio jurídico gênero, é, no dizer de GAGLIANO; PAMPLONA FILHO, verbis: "...a convergência das manifestações de vontades contrapostas, formadora do denominado consentimento.".54

E qual seria a natureza jurídica do contrato entre o médico e o paciente? FARIAS; ROSENVALD o apresentam como exemplo de um contrato de prestação de serviços. GAGLIANO; PAMPLONA FILHO, por seu turno, assim definem essa espécie de contrato, verbis: “...é o negócio jurídico por meio do qual uma das partes, chamada prestador, se obriga a realizar uma atividade em benefício de outra, denominada tomador, mediante remuneração". ${ }^{5}$

Dessa forma, podemos entender que o contrato médico é da espécie prestação de serviços que, por tal, envolve atividade profissional, contrato esse que, como ato complexo, obriga o profissional (o prestador) ao desempenho de ações, encargos, atribuições, serviços, relacionados ao

${ }^{52}$ AZEVEDO, A. J. Negócio Jurídico: Existência, Validade e Eficácia. $8^{\text {a }}$ tir. São Paulo: Saraiva, 2013, p. 16.

${ }^{53}$ FARIAS, C.C. de \& ROSENVALD, N. Curso de Direito Civil: Contratos. $5^{\text {a }}$ ed. São Paulo: Atlas, 2015, v.4, p. 32.

${ }^{54}$ GAGliano, P.S. e PAMPlONA FILHO, R. Novo Curso de Direito Civil: Contratos. Teoria Geral. $2^{a}$ ed. ver. atual. ref. São Paulo: Saraiva, 2006. v.4 (1). p. 54.

${ }^{55}$ FARIAS, C.C. de \& ROSENVALD, N. Curso de Direito Civil: Contratos. $5^{\text {a }}$ ed. São Paulo: Atlas, 2015, v.4, p. 748. 
diagnóstico e tratamento do paciente (o tomador), mediante contraprestação. Tal atividade profissional refere-se a este "conjunto de atos praticados por um sujeito [o médico], em decorrência do exercício do seu ofício (profissão autônoma ou subordinada)". Em assim sendo, os autores (p.204), no estudo da responsabilidade civil, instituto em que se observa o descumprimento de obrigações avençadas, estas, fruto do que, dentre outros tipos de contratos, pode ser um contrato de prestação de serviços, reconhecem que "estaremos sempre, em regra, no campo da responsabilidade civil contratual". 56

Na espécie de contrato de prestação de serviços, não se observa a situação de hierarquização, já que o prestador não se subordina ao tomador, pois que os diversos atos que pratica estão exclusivamente sob seu próprio crivo e determinação. Contudo, é importante observar que, no ato médico, há uma diferença importantíssima, posto que o tomador, ou seja, o paciente, é, por vezes, parte ativa nos métodos empregados pelo médico, já que aqui, como discutido em capítulos anteriores, exsurge o instituto da autonomia do paciente, ancorado este no Diploma Civil e no próprio Código de Ética Médica.

Trata-se, portanto, de contrato sui generis, pois, embora decida o médico sobre os métodos a serem empregados, necessário será, em ocasiões específicas, submeter-se a decisões do paciente, como dispõe o art. 15 do Código Civil, verbis: "Ninguém pode ser constrangido a submeter-se, com risco de vida, a tratamento médico ou a intervenção cirúrgica". Notese que, nesse sentido, o acompanha o Código de Ética Médica, como já assinalado no Capítulo 1 desse trabalho, verbis:

\begin{abstract}
Art. 31: É vedado ao médico:
Desrespeitar o direito do paciente ou de seu representante legal de decidir livremente sobre a execução de práticas diagnósticas ou terapêuticas, salvo em caso de iminente risco de morte.
\end{abstract}

Importante assinalar que, embora sob o pálio da regulamentação consumerista, não se exclui a submissão do contrato médico, também, não

\footnotetext{
${ }^{56}$ GAgliano, P.S. e PAMPlona FILHO, R. Novo Curso de Direito Civil: Contratos. Teoria Geral. $2^{a}$ ed. ver. atual. ref. São Paulo: Saraiva, 2006. v.4 (1)., p. 204.
} 
somente às regras da Lei Civil, como, igualmente, às do Código de Ética Médica, consagrando espaço à tese do chamado diálogo das fontes, expressão cunhada por ERIK JAYME, difundida entre nós pela jurista CLAUDIA LIMA MARQUES, que ressalta a importância do, verbis:”...atual e necessário 'diálogo das fontes' (dialogue des sources) a permitir a aplicação simultânea, coerente e coordenada das plúrimas fontes legislativas convergentes". 57

Reconhece MARQUES que o direito pátrio já consagra o instituto em seus julgados, inclusive em decisões do STJ, lembrando ainda TARTUCE que "a aplicação do diálogo das fontes justifica-se no Brasil diante de uma aproximação principiológica entre os dois sistemas legislativos (CDC e CC/2002), principalmente no que tange aos contratos". ${ }^{58}$

Em se tratando o contrato médico, de prestação de serviços médicos, um ato complexo, composto de ações, atribuições, serviços, encargos, todos devidamente incluídos nesse ato, tem-se que as Diretivas Antecipadas de Vontade, objeto de nosso trabalho, especificamente trata das ações a serem praticadas pelo médico assistente, referentes ao, verbis:

art. 10.... conjunto de desejos, prévia e expressamente manifestados pelo paciente, sobre cuidados e tratamentos que quer, ou não, receber no momento em que estiver incapacitado de expressar, livre e autonomamente sua vontade.

Nesse contrato, é de suma importância a manifestação de vontade do médico-assistente, quanto à concordância com os desejos do paciente, visto que será ele que determinará o momento da aplicação desses desejos, que será o agente que praticará as ações necessárias para a instituição do tratamento indicado e que será aquele que irá dispensar alguns procedimentos, enquanto administrará outros, esses representados pelos cuidados paliativos, mesmo porque a abjuração de procedimentos considerados excepcionais e inúteis, para aquele determinado paciente, não irá implicar,

57 MARQUeS, C.L.; BenJaMin, A.H.V.; MIRAGEM, B. Comentários ao Código de Defesa do Consumidor. 3ed. rev. atual. amp. São Paulo: RT, 2010, p. 32.

58 TARTUCE, F. Direito Civil: Teoria Geral dos Contratos e Contratos em Espécie. 8ed. ver. atual. amp. São Paulo: Método, 2013. v.3, p. 101. 
em nenhuma circunstância, em abandoná-lo à sua própria sorte. É preciso, afirmamos, que o médico, como parte ativa dessa declaração de vontade, esteja cônscio do papel fundamental que irá desempenhar nesse contrato, certificando-se de não ter objeções de consciência, ao dever rejeitar procedimentos médicos avançados tecnicamente, em favor de outros ditos conservadores.

Imperativo lembrar que tais cuidados, chamados paliativos, necessitam de obedecer à proporcionalidade entre os procedimentos realizados e os resultados esperados; à prevenção das possíveis complicações inerentes à própria doença de que padece o paciente; e ao atendimento efetivo para o alívio da dor. Não resta dúvida de que o papel do médico, nesse serviço prestado, excede de muito aquele comumente exercido nos tratamentos médicos ditos comuns, já que, no caso em apreço, estará o profissional lidando com os sentimentos mais profundos do ser humano, aqueles intimamente relacionados ao final da existência humana e que, provavelmente, pela sua enorme carga emocional, estarão muito além do valor patrimonial recebido pelo seu trabalho. ${ }^{59}$

Ainda quanto ao papel do médico como parte ativa na prestação do serviço em questão, deparamo-nos com o $\S 2^{\circ}$ do artigo $2^{\circ}$ das Diretivas Antecipadas, em que cabe ao profissional verificar a conformidade de tais diretivas com o que dispõe o Código de Ética Médica, in verbis: "O médico deixará de levar em consideração as diretivas antecipadas de vontade que, em sua análise, estiverem em desacordo com os preceitos ditados pelo Código de Ética Médica". ${ }^{60}$

Dessa feita, é o médico a parte que irá decidir da aplicabilidade ética, conforme os ditames do Código de Ética Médica, das Diretivas Antecipadas de Vontade, com o poder de bloquear qualquer medida que considere fora dos preceitos éticos do que determina seu diploma ético. Eis aí mais uma participação ativa e efetiva da parte do médico assistente nesse contrato tão original.

Percebe-se, então, que o contrato Diretivas Antecipadas de Vontade é contrato de prestação de serviços médicos, resultado de duas manifestações de vontade: a do paciente em ver cumpridos seus desejos quanto

${ }^{59}$ DADALTO, L. et al. Diretivas Antecipadas de Vontade: um modelo brasileiro. Bioética. Brasília, CFM, 2013, 21(3), p. 113.

${ }^{60}$ DADALTO, L. et al. Diretivas Antecipadas de Vontade: um modelo brasileiro. Bioética. Brasília, CFM, 2013, 21(3), p. 113. 
ao método terapêutico desejado, caso esteja em estágio terminal de doença e incapaz, naquela oportunidade, de manifestar tal vontade; e a do médico assistente, em diagnosticar esse momento e estabelecer o adequado método terapêutico paliativo para este paciente, além de certificar-se da consonância das Diretivas de Vontade do paciente aos preceitos éticos dispostos pelo Código de Ética Médica. Essas manifestações de vontade, por sua vez, estarão consubstanciadas numa declaração de vontade una, unindo as manifestações de vontade de ambas as partes, e será expressa em documento próprio.

Ao tratarmos da avaliação do contrato das Diretivas Antecipadas de Vontade, é no plano da validade que repousa sua maior importância, pois que se ambas as partes, médico e paciente, como em qualquer contrato, devem ser agentes capazes juridicamente, é o paciente que, dado o estado mórbido de que é vítima e a qualidade importantíssima da decisão que irá tomar, deverá ter sua capacidade mental cuidadosamente apreciada pelo médico e, se necessário, por perito médico, no que tange à sua lucidez, e consequente discernimento, quanto às diretivas que deseja sejam tomadas pelo médico-assistente.

Somente após analisado e constatado válido o referido contrato, poderá este exercer a sua eficácia no momento em que se mostrar necessária a sua aplicação. É importante que se entenda que, como se trata de situação excepcional, em que o paciente opta pelo tratamento conservador ou paliativo, em lugar de métodos invasivos e, principalmente, pela sua característica de um contrato sem prazo, ambas as partes podem extinguir o referido contrato, como dispõe o artigo 599, caput, do Código Civil Brasileiro, verbis: "Não havendo prazo estipulado, nem se podendo inferir da natureza do contrato, ou do costume do lugar, qualquer das partes, a seu arbítrio, mediante prévio aviso, pode resolver o contrato. '

Entretanto, a ausência de prazo determinado exige a aplicação do princípio da boa-fé objetiva, via seus deveres anexos de confiança, lealdade, colaboração, quando a parte que desiste avisa à outra, com intervalo de tempo suficiente, para que esta tome as providências necessárias, tudo objetivando o equilíbrio contratual. No caso de desistência do médico, dispõe o Código de Ética Médica, em seu Capítulo III, artigo 36, verbis:

Capítulo III: É vedado ao médico art. 36: Abandonar paciente sob seus cuidados. 
§ 10 - Ocorrendo fatos que, a seu critério, prejudiquem o bom relacionamento ou o pleno desempenho profissional, o médico tem o direito de renunciar ao atendimento, desde que comunique previamente ao paciente ou a seu representante legal, assegurando-se da continuidade dos cuidados e fornecendo todas as informações necessárias ao médico que lhe suceder. (grifo nosso)

§ 20-Salvo por motivo justo, comunicado ao paciente ou aos seus familiares, o médico não abandonará o paciente por ser portador de moléstia crônica ou incurável e continuará a assisti-lo ainda que para cuidados paliativos. (grifo nosso)

Chama a atenção TARTUCE, muito apropriadamente, que a razão para a extinção do contrato em estudo não é a de que cuida o citado dispositivo, ou seja, a de um descumprimento de obrigação, mas, sim, a do exercício"...de um direito potestativo que a parte tem em relação à extinção, nos termos do art.473, caput, do Código Civil em vigor.'Portanto, conclui o autor,"...não se trata de resolução propriamente dita, mas de resilição unilateral". ${ }^{61}$

Quanto à denominação do contrato, é importante salientar, que As Diretivas Antecipadas de Vontade (advanced care documents), consideradas como gênero, do qual são espécies o Testamento Vital (living will) e o Mandato Duradouro, surgiram na década de 60, do século passado, nos Estados Unidos da América, como já mencionamos no Capítulo 3 desse trabalho. Assim são definidos por DADALTO tais documentos: o Testamento Vital refere-se "a instruções acerca de futuros cuidados médicos aos quais uma pessoa que esteja incapaz de expressar sua vontade será submetida, antes de um diagnóstico de terminalidade da vida"(grifo nosso); já o Mandato Duradouro, é um documento em que é nomeado um procurador, ou mais de um, de reconhecida autoridade pelos médicos, para que, em presença de um estado de incapacidade temporária ou definitiva, ou de dificuldade de expressão pelo paciente, possa "tomar alguma decisão sobre

61 TARTUCE, F. Direito Civil: Teoria Geral dos Contratos e Contratos em Espécie. 8ed. ver. atual. amp. São Paulo: Método, 2013. v.3, p. 445. 
tratamento ou procedimento. Saliente-se que o procurador de saúde decidirá com base na vontade do paciente". ${ }^{6}$

Consequentemente, as Diretivas Antecipadas de Vontade, como gênero, não se destinam apenas a situações de terminalidade da vida, bem assim a espécie Mandato Duradouro, enquanto a espécie Testamento Vital, como se entende o negócio jurídico unilateral "testamento", dessas situações finais cuida especificamente.

Nessa linha de raciocínio, a leitura cuidadosa do texto completo da dita Resolução, repitamos, não se encontra, em nenhuma parte desta, qualquer referência à terminalidade da vida, tais diretivas referem-se claramente a estar o paciente"...incapacitado de expressar, livre e autonomamente a sua vontade"(art. 1ㅇ, caput), ou mesmo, aos"...pacientes que se encontram incapazes de comunicar-se, ou de expressar de maneira livre e independente suas vontades"(art. 2을 caput). Portanto, a palavra-chave é incapacidade de expressão, situação que pode ser encontrada, tanto no paciente na terminalidade de sua existência, quanto naquele vítima de uma doença grave que, embora ainda não terminal, não possua esperanças de cura ou de mero alívio, mas que não lhe permita expressar sua opção pela forma de tratamento desejada. Em assim sendo, acreditamos que o termo Testamento Vital, mais utililizado no mundo jurídico, deva ser substituído, data vênia, pelo Diretivas Antecipadas de Vontade, devido a sua maior adequação aos objetivos de que se reveste.

Precisamente, ao analisarmos o texto da Resolução 1995/2012 do Conselho Federal de Medicina, dispondo sobre as Diretivas Antecipadas de Vontade do paciente, vislumbramos no parágrafo $1^{\circ}$ do art. $2^{\circ}$, a presença do Mandato Duradouro, verbis: "Caso o paciente tenha designado um representante para tal fim, suas informações será levadas em consideração pelo médico", embora note-se um cuidado extremo com a preponderância dos desejos do paciente, pelo disposto no parágrafo $3^{\circ}$, verbis: "As diretivas antecipadas do paciente prevalecerão sobre qualquer outro parecer não médico, inclusive sobre os desejos dos familiares".

Na melhor linha de interpretação dos tempos pós-modernos, esse contrato tão pessoal, em que o paciente transmite ao médico seus desejos, quanto ao tratamento a que deseja ser, ou não ser, submetido nos momentos

${ }^{62}$ DADALTO, L. et al. Diretivas Antecipadas de Vontade: um modelo brasileiro. Bioética. Brasília, CFM, 2013, 21(3), p. 107. 
finais de sua vida, na verdade, envolve efeitos predominantemente existenciais, embora de conteúdo patrimonial no que se refere aos honorários médicos. E este conteúdo existencial não apenas fala de perto aos interesses das partes contratantes, mas, igualmente, aos familiares, amigos e equipe médica, que irão estar intimamente relacionados aos cuidados assistenciais nesses momentos tão decisivos. Mais ainda, observa-se, também, que tais decisões por parte de pacientes terminais, aprovadas pelos profissionais que os assistem, irão influenciar sobremaneira o posicionamento da sociedade como um todo, no que se relaciona à convivência com o final da existência humana. Dessa feita, podemos entender que cuidamos aqui de um contrato de vida digna, porque ele permite ao paciente viver uma vida digna até a sua morte, ou seja, dignificamos a vida para dignificarmos a morte!

Importante lembrar que estamos falando de um contrato sob a égide do conceito contemporâneo ou pós-moderno do contrato, em que este não tem obrigatoriamente tão somente conteúdo patrimonial, como exigido pelo conceito clássico ou moderno, mas, também, efeitos existenciais importantíssimos, na proteção da dignidade da pessoa humana. Sendo fruto de uma relação intersubjetiva, esse novo contrato é entendido como tendo "a principal função de atender à pessoa e aos interesses da coletividade diante da tendência de personalização do Direito Privado". Dessa forma, portanto, ele gera efeitos não somente para as partes contratantes, como igualmente em relação a terceiros. É o que se denomina de função social do contrato. ${ }^{63}$

\subsection{FUNÇÃO SOCIAL DO CONTRATO DAS DIRETIVAS ANTECIPADAS DE VONTADE}

Se estivéssemos sob a égide do Código Civil de 1916, ao celebrarmos tal contrato, bastaria que nos preocupássemos com a capacidade das partes contratantes, com a licitude, possibilidade e determinabilidade do objeto, bem assim com a forma, se prescrita ou não vedada em lei (art. 104, CC - 1916 e 2002).

${ }^{63}$ TARTUCE, F. A Função Social dos Contratos, a Boa-Fé objetiva e as Recentes Súmulas do Superior Tribunal de Justiça. A Função Social dos Contratos: Do Código de Defesa do Consumidor ao Novo Código Civil. São Paulo: Método, 2005., p. 4. 
Entretanto, face à funcionalização do Direito Civil Brasileiro, decorrente da visão socializante da Constituição Brasileira de 1988, o instituto da função social vem permear toda a interpretação civilista e o direito contratual não poderia fugir a tal situação, como dispõe o art.421, do diploma civil, verbis: "A liberdade de contratar será exercida em razão e nos limites da função social do contrato.

E o que é a função social do contrato? TARTUCE nos ensina que, pela função social dos contratos, estes devem ser interpretados e visualizados de acordo com o contexto social em que se inserem: "Não pode o contrato trazer onerosidades excessivas, desproporções, injustiça social. Também não podem os contratos violar interesses metaindividuais ou interesses individuais relacionados com a proteção da dignidade humana". ${ }^{64}$

Ora, se o contrato tem que obedecer à função social de forma tão extensa e abrangente, a consequência evidente é que é a função social que confere eficácia ao contrato e esta eficácia verifica-se internamente, ou seja, entre as partes e externamente, na geração de efeitos perante terceiros (extra partes).

Tratando-se de efeitos entre as partes, à guisa de exemplo, o art. 413, do Código Civil, determina, que "o juiz deve reduzir o valor da cláusula penal se a obrigação tiver sido cumprida em parte ou se entender que a multa é excessivamente onerosa". ${ }^{65}$

Quanto aos efeitos extra partis, TARTUCE cita exemplo de contrato correto entre as partes, mas nocivo à sociedade, pois, "a publicidade veiculada é discriminatória. (...) Pela presença do abuso de direito, o contrato pode ser tido como nulo,...". ${ }^{66}$

${ }^{64}$ TARTUCE, F. A Função Social dos Contratos, a Boa-Fé objetiva e as Recentes Súmulas do Superior Tribunal de Justiça. A Função Social dos Contratos: Do Código de Defesa do Consumidor ao Novo Código Civil. São Paulo: Método, 2005., p. 4.

${ }^{65}$ TARTUCE, F. A Função Social dos Contratos, a Boa-Fé objetiva e as Recentes Súmulas do Superior Tribunal de Justiça. A Função Social dos Contratos: Do Código de Defesa do Consumidor ao Novo Código Civil. São Paulo: Método, 2005., p. 3.

${ }^{66}$ TARTUCE, F. A Função Social dos Contratos, a Boa-Fé objetiva e as Recentes Súmulas do Superior Tribunal de Justiça. A Função Social dos Contratos: Do Código de Defesa do Consumidor ao Novo Código Civil. São Paulo: Método, 2005., p. 4. 
Dessa forma, percebe-se claramente que a função social do contrato é o elemento arrefecedor, por excelência, da autonomia privada, que envolve a liberdade (iniciativa) de contratar e a liberdade (conteúdo) contratual, bem assim do princípio pacta sunt servanda, ou seja, o contrato é lei entre as partes (força obrigatória dos contratos).

Mais ainda, a função social, em sua eficácia externa, preocupase com os efeitos externos do contrato, ou seja, sua influência na esfera de terceiros, possíveis interferências sociais, no meio ambiente, etc. Como ensina GAGLIANO; PAMPLONA FILHO, é preciso que o contrato seja "visto sob o aspecto eficacial na sociedade em que fora celebrado". ${ }^{67}$

Depreendemos, então, que a função social dos contratos é instituto obrigatório na interpretação contratual e, caso tenha sido olvidado na celebração de qualquer contrato, este deverá ser considerado nulo, pois que, "a violação da função social do contrato traduzir-se-ia, sem dúvida, em inegável retrocesso em nossa nova ordem jurídica". ${ }^{68}$

\subsubsection{A eficácia externa da função social}

Claro está que importantes influências dar-se-ão no comportamento da sociedade a que pertencemos, ao tomar-se conhecimento de que, em determinados momentos, não mais se deverá perseguir obstinadamente uma vida que não mais se entende como tal, mas que se poderá morrer no tempo certo, em condições de apoio doméstico e familiar, com os cuidados de que toda pessoa humana é merecedora.

Quantas dúvidas, motivadas por crenças de vários matizes, de religiosas a científicas, aquelas na visão de que há sempre vida, mesmo que inútil, mesmo que indigna, estas, escudadas em ideias de que se devem utilizar todos os métodos e sempre, mesmo que estes não mais se justifiquem, a não ser porque existem!

${ }^{67}$ GAGlianO, P.S. e PAMPlONA FILHO, R. Novo Curso de Direito Civil: Contratos. Teoria Geral. $2^{a}$ ed. ver. atual. ref. São Paulo: Saraiva, 2006. v.4 (1)., p. 46.

${ }^{68}$ GAGlianO, P.S. e PAMPlONA FILHO, R. Novo Curso de Direito Civil: Contratos. Teoria Geral. $2^{a}$ ed. ver. atual. ref. São Paulo: Saraiva, 2006. v.4 (1)., p. 49. 
Entretanto, não se descuidando das várias consequências que se irão descobrindo no desenvolver desses novos conceitos, exsurge a importância do ser humano como o titular do seu direito a viver dignamente e a morrer como tal, com seus desejos mais legítimos atendidos, tornando assim sua existência o mais humana possível.

E quanto aos familiares? Nem sempre estes conseguem a entender a gravidade da situação do ente querido, frente aos estágios terminais de doença grave, pois 'também os membros da família experimentam diferentes estágios de adaptação, semelhantes aos descritos com referência aos pacientes". ${ }^{69}$

No primeiro estágio, tem-se o sentimento de negação, em que a família não pode acreditar que seja verdade e procura freneticamente por outras opiniões e prognósticos. O estágio seguinte caracteriza-se pela raiva do médico que lhes apresenta, com o diagnóstico, a certeza da triste realidade. Em momento posterior, observa-se, a depressão, estágio que prescinde de palavras e prepara-se para a aceitação, que "caracteriza-se por um período de desligamento gradativo de eventos e problemas do mundo exterior", ${ }^{70}$

O médico, ao examinar essa evolução da existência de um paciente terminal, ou em vias de o ser, poderá situar melhor as reações de seus familiares e do próprio paciente, o que lhe irá permitir encontrar o melhor momento para entender tais reações e encontrar o momento mais propício, ou seja, aquele mais justo, para construir as Diretivas Antecipadas de Vontade a serem seguidas. Como acentuam COELHO; FERREIRA, verbis: "Morrer é, portanto, um árduo trabalho interior, possível de ser realizado com mais ou com menos consciência. É uma espécie de parto de si mesmo."Afirmação perfeitamente verdadeira para todos os envolvidos nesses momentos. ${ }^{71}$

Igualmente importante é o reconhecimento de que uma série de conflitos irão resultar do embate entre sentimentos tão contraditórios, haja vista que essa aparente evolução em estágios, não necessariamente dá-se

${ }^{69}$ COELHO, M.E.M. \& FERRARA, A.C. Cuidados Paliativos: narrativas do sofrimento na escuta do outro. Bioética. Brasília: CFM, 2015, 23(2), p. 342.

${ }^{70}$ COELHO, M.E.M. \& FERRARA, A.C. Cuidados Paliativos: narrativas do sofrimento na escuta do outro. Bioética. Brasília: CFM, 2015, 23(2), p. 343.

${ }^{71}$ COELHO, M.E.M. \& FERRARA, A.C. Cuidados Paliativos: narrativas do sofrimento na escuta do outro. Bioética. Brasília: CFM, 2015, 23(2), p. 345. 
no mesmo tempo para todos os personagens, o que irá determinar sérios problemas entre o médico, o paciente e seus familiares. Exatamente para auxiliar na resolução de tais conflitos e buscando respeitar os desejos e preferências do maior interessado, o paciente, é que essa Resolução 1995, dispõe em seu art. 2오을
“...as diretivas antecipadas do paciente prevalecerão sobre qualquer outro parecer não médico, inclusive sobre os desejos dos familiares".

Eles serão certamente os mais atingidos diretamente pelas Diretivas Antecipadas de seu ente querido e, embora estas sejam plenamente obedecidas, a eles deverão ser fornecidas as melhores e mais claras informações sobre a doença do seu paciente e o porquê de suas decisões, já que na medida em que estejam corretamente informados, serão eles que lhe irão dispensar toda a assistência de que necessitará dali em diante.

É evidente que a morte ainda continuará sendo aquela inimiga a ser vencida, na visão de grande parte dos seres humanos, haja vista as inúmeras tentativas de manter-se jovem, seja pela alimentação dita saudável, seja pelo dia a dia nas academias, seja por meio de medicamentos, seja pelas cirurgias plásticas, entretanto, poder o ser humano exercer o direito a decidir morrer no momento certo, nem antes, nem depois, poderá ser uma forma de reduzir um pouco o peso do momento final.

\subsubsection{A eficácia interna da função social}

Ou eficácia inter partis da função social, no contrato das Diretivas Antecipadas de Vontade, situa-se no coração mesmo da delicada relação médico-paciente. Delicada porque, num momento grave, de muito sofrimento, de sentimentos contraditórios, carregados, por vezes, de grande revolta, em que a mente pode encontrar-se prisioneira de um inconformismo agressivo contra tudo e todos, é que o profissional médico precisa esclarecer as dúvidas, explicar os procedimentos de forma claramente inteligível para leigos, entender as objeções por motivos, às vezes, fúteis, mas que evidenciam o medo terrível de que os pacientes podem ser tomados. 
Momentos em que o médico necessitará avaliar a capacidade de discernimento do paciente quanto às diretivas por ele expressas. Se manifestadas em momentos anteriores às situações de terminalidade ou de inconsciência, não deverá haver maiores problemas. Mas, o que fazer se elas vierem no bojo dos momentos críticos, em que decisões gravíssimas devem ser tomadas? Naturalmente, necessitar-se-á de avaliação específica profissional, que, talvez, o médico assistente não possua. Teremos, então, a entrada em cena de um outro profissional, desconhecido do paciente, que irá avaliá-lo naquela esfera que lhe é mais sensível, a mental. Quem ou o quê irá regular esse fazer?

Por outro lado, como irá se sentir e, consequentemente, se posicionar o médico frente às diretivas antecipadas expressas pelo paciente que assiste? Concordará ele com tais assertivas? Aceitará ele que os tratamentos apontados como excluídos pelo paciente podem efetivamente sê-los? Se não concordar, o que é de seu direito, poderá ser substituído por outro colega? Como tal se dará? O paciente deverá participar da escolha desse novo médico?

\subsection{0 imperativo de consciência do médico}

O direito fundamental à liberdade de pensamento, consagrado no artigo 5o, inciso IV, de nossa Lei Maior, verbis: "é livre a manifestação do pensamento, sendo vedado o anonimato.", compreende a liberdade de foro íntimo, em que não se pode ser constrangido a pensar de forma prédeterminada; e a liberdade de consciência e de crença, em que não pode haver qualquer obstáculo quanto às convicções políticas, filosóficas e religiosas do indivíduo. ${ }^{72}$

Embora o direito à liberdade de pensamento esteja contida no direito à liberdade de forma genérica, merece destaque em nível constitucio-

\footnotetext{
${ }^{72}$ FERREIRA FILHO, 1994, apud GAGLIANO, P.S. e PAMPLONA FILHO, R. Novo Curso de Direito Civil: Parte Geral. $17^{\text {a }}$ ed. São Paulo: Saraiva, 2015. v.1, p. 218 .
} 
nal como um direito autônomo, pois representa de maneira significativamente específica "a forma de expressão de individualidade do ser humano". 73

Em assim sendo, todo indivíduo, no seu íntimo, tem a total liberdade de pensar como quiser a respeito de toda e qualquer situação em que se encontre, trate-se de crença religiosa, ou mesmo de sua ausência, tratese de crença política, de convicção filosófica, ou mesmo de aspectos relacionados a sua saúde.

Lembra SILVA que em sua dimensão mais interna, "como pura consciência, pura crença, mera opinião, a liberdade de pensamento é plenamente reconhecida, mas não cria problema maior." Mais ainda, "está fora de todo o poder social, até então é do domínio somente do próprio homem, de sua inteligência e de Deus". ${ }^{74}$

No entanto, tem-se uma situação bastante diversa, quando o indivíduo sente, ou percebe, a necessidade de expressar seu pensamento e, nesse momento, nossa Constituição Republicana de 1988 protege e garante seu direito fundamental, com inviolabilidade, à liberdade de consciência e de crença, no art. 5o, verbis:

VI: é inviolável a liberdade de consciência e de crença, sendo assegurado o livre exercício dos cultos religiosos e garantida, na forma da lei, a proteção aos locais de culto. (grifo nosso)

E a sua liberdade de crença religiosa e de convicção filosófica ou política, no mesmo artigo, verbis:

VIII: ninguém será privado de direitos por motivo de crença religiosa ou de convicção filosófica ou política, salvo se as invocar para eximir-se de obrigação legal a todos imposta e recusar-se a cumprir prestação alternativa, fixada em lei.

${ }^{73}$ GAGlianO, P.S. e PAMPlONA FILHO, R. Novo Curso de Direito Civil: Parte Geral. 17 a ed. São Paulo: Saraiva, 2015. v.1, p. 218.

74 PIMENTA BUENO, J.A. apud SILVA, J.A. da. Curso de Direito Constitucional Positivo. 18 a ed. São Paulo: Malheiros Editores, 2000, p. 244. 
Evidentemente que, no caso de uma "obrigação legal a todos imposta, que podem ser eximidas por motivo de crença religiosa ou convicção filosófica ou política" ${ }^{75}$, há que se prever, na forma da lei, alternativa para o cumprimento de tal obrigação, como se observa, mais comumente, na obrigatoriedade da prestação de serviço militar, quando a Constituição dispõe, verbis:

Art. 143 §1o: “Às Forças Armadas compete, na forma da lei, atribuir serviço alternativo aos que, em tempos de paz, após alistados, alegarem imperativo de consciência, entendendo-se como tal o decorrente de crença religiosa e de convicção filosófica ou política, para se eximir de atividades de caráter essencialmente militar.

Todavia, situações há que, por não se constituir em obrigações a todos impostas, já que envolvem atos restritos à autonomia privada das partes, que se mostram capazes, cujo objeto é lícito e a forma não é defesa em lei, demandam análise mais cuidadosa e específica, para que os direitos fundamentais daquele que alega o imperativo de consciência não sejam perdidos, ou mesmo, suspensos.

É da liberdade de consciência que deriva o direito individual do imperativo de consciência, pois é essa liberdade que "constitui-se no núcleo básico de onde derivam as demais liberdades de pensamento". ${ }^{76}$

É de se lembrar que a liberdade de pensamento permite que o indivíduo guarde este para si, recolha-o para o seu interior, dele não dando conhecimento ao mundo exterior, constituindo-se em direito fundamental, assegurado pela Constituição da República de 1988, ou seja o direito de ficar calado, de grande valia no direito criminal, verbis:

Ar. 5o inc. XVIII: O preso será informado de seus direitos, entre os quais o de permanecer calado,

${ }^{75}$ SILVA, J.A. da. Curso de Direito Constitucional Positivo. $18^{\mathrm{a}}$ ed. São Paulo: Malheiros Editores, 2000, p. 248.

76 MORAES, A. de. Constituição do Brasil Interpretada e Legislação Constitucional. $8^{\text {a }}$ ed. São Paulo: Atlas, 2011., 2011, p. 142. 
sendo-lhe assegurada a assistência da família e de advogado.

Por outro lado, poderá o indivíduo desejar, ou mesmo, ser instado a manifestar de forma expressa seu pensamento, seja por impulso próprio ou por necessidade de se furtar à prática de algum ato que repute impróprio quanto à sua consciência. Igualmente, em tais momentos, o texto constitucional solidifica o direito de manifestar seu pensamento, ou seja, o direito de sair das muralhas de seu foro íntimo e torná-lo público, sob qualquer meio ou forma lícitos, como disposto no art. 220, verbis:

Art. 220, caput: a manifestação do pensamento, a criação, a expressão e a informação, sob qualquer forma, processo ou veículo não sofrerão qualquer restrição, observado o disposto nesta Constituição.

Dessa forma, temos que a manifestação do pensamento se poderá dar entre pessoas determinadas, de maneira informal, como em uma conversa, ou de maneira formal, por meio expresso, como por documentos, ou ainda entre pessoas indeterminadas, de forma pública e assim por diante. Portanto, a manifestação do pensamento, expressa em um imperativo de consciência, está protegida pela Lei Maior em todas as suas formas, consentânea com a vontade do indivíduo que a emite e livre de quaisquer ingerências externas a sua vontade.

Qual a razão para estarmos nesse trabalho, referente às Diretivas Antecipadas de Vontade, cuidando desse tema: imperativo de consciência do médico? Lembramos, então, que discutimos, em capítulo anterior, nosso entendimento de que se tratam as Diretivas Antecipadas de Vontade de um contrato, que expressa uma declaração de vontade, composta esta, por sua vez, de duas manifestações de vontade, reunidas em um acordo, resultado, portanto, de uma construção das partes, acordo esse que converge diretamente para um objetivo comum.

"Não se pode negar a formação de um autêntico contrato entre o cliente e o médico quando este o atende", são palavras, igualmente por nós 
já referidas anteriormente, do grande jurista GONÇALVES ao analisarmos a relação médico-paciente. ${ }^{77}$

Portanto, constituem-se as Diretivas Antecipadas de Vontade em um contrato de prestação de serviços médicos, em que ambas as partes, o paciente e o médico, contraem obrigações muito bem definidas, a saber: na dimensão do paciente, este tem a autonomia de decidir a quais condutas médicas extraordinárias e invasivas deseja, ou não, se submeter, frente a uma situação mórbida em que não aufere mais benefícios, quanto a perspectivas de cura ou mesmo de alívio de seus sofrimentos, E, em outra dimensão, encontramos o médico, que tem não uma, mais várias obrigações diferentes entre si, para fazer frente a tal desejo do paciente.

O manifestação de vontade do médico, como parte nesse contrato, é de suma importância, no que tange à decisão do paciente de recusar tratamentos e exames invasivos, dos quais não aufere mais os resultados esperados. Deve-se tal importância, por ser ele quem vai dispensar tais medidas, quem irá determinar se o momento é apropriado para essa dispensa, como dispõe a já citada Resolução 1995, verbis:

Art. 20 \$2:- O médico deixará de levar em consideração as diretivas antecipadas de vontade que, em sua análise, estiverem em desacordo com os preceitos ditados pelo Código de Ética Médica". (grifo nosso)

Nessa linha de raciocínio, é o médico que irá verificar e aceitar, ou não, as Diretivas, frente às considerações éticas contidas em seu Código de Ética.

A capacidade do paciente em entender corretamente o estado mórbido de que é vítima e ter o discernimento necessário para uma tomada de decisão tão importante, terá que ser estimada pelo médico, que, caso ache necessário, deverá pedir avaliação de perito médico, no que tange ao estado mental do paciente.

Ao concluirmos pela validade desse contrato, ou seja, em que as partes são efetivamente capazes, em que o objeto é lícito, possível e determinado e a forma já prescrita, temos que no plano da eficácia, mais uma

${ }^{77}$ GONÇALVES, C.R. Direito Civil Brasileiro: Responsabilidade Civil. $2^{\mathrm{a}}$ ed. ver. atual. São Paulo: Saraiva, 2007. v.4, p. 238. 
vez é o médico que o determina, pois é ele quem avalia o momento em que ele exerce seus efeitos, ou seja, o momento em que constata a irreversibilidade do quadro mórbido do paciente.

É exatamente esse o momento decisivo e mais difícil para o médico, quando ele estará, finalmente, frente às suas convicções, sejam elas técnicas, sejam sociais, sejam religiosas.

Durante toda a sua formação médica, lhe foi ensinado, e ele aprendeu, a evitar a morte, a driblá-la, a vencê-la. Sempre foi sua obrigação lutar sempre e sempre contra ela. Nunca aprendeu, ou lhe foi ensinado, a tentar entendê-la e, quem sabe, aceitá-la, quando as esperanças se esvaem. Morte sempre foi vista e sentida como a derrota que deveria ter sido evitada, se tivesse feito seu trabalho direito. A sociedade espera, e exige, que ele derrote a morte, que a espante para longe para que nunca mais volte e, assim, nos faça a todos imortais.

Por sua vez, suas convicções religiosas o obrigam a permanecer mais e mais nessa luta que ele sabe inglória, que ele sabe perdida. Com a visão enevoada pela obrigação de salvar vidas, de não aceitar a morte, os sinais vitais do paciente, sua lucidez ainda presente, são seu norte, seu objetivo profissional. Enquanto o paciente os tem, o médico insiste, mesmo que tais sinais existam apenas artificialmente, mantidos por aparelhos que nada acrescentam, porque aquela realidade, certamente não é mais vida.

E esse médico se recusa a aceitar a morte de seu paciente e não desliga o armamentário tecnológico, se recusa a atender seus pedidos de descanso, sua desistência de lutar contra o inevitável. Ele não aceita as diretivas do paciente e, alegando imperativo de consciência, se afasta, se refugia em suas crenças, porque agora ele só pode acreditar, já que não há mais lugar para a razão.

Nesses momentos nunca nos lembramos desse lado do contrato, o paciente ocupa toda nossa compreensão e não aceitamos uma negativa do médico em cumprir as Diretivas, o entendemos como parte devedora no contrato, pressupomos que o obedecerá sem dúvidas. Mesmo a Resolução 1995 somente se ocupa com a recusa do médico caso as Diretivas estejam”...em desacordo com os preceitos ditados pelo Código de Ética Médica".(art. $2^{\circ} \S 2^{\circ}$, in fine).

Chega-se ao ponto de encontrarmos autores como CRUZ; OLIVEIRA, que entendem tal recusa como negligência, responsabilizando civilmente o médico, verbis: 
Ao rechaçar a declaração de vontade do paciente em fase terminal que requer a suspensão de tratamentos extraordinários, o médico age com culpa sob a forma de negligência, o que resulta em dano moral, pois feridas a dignidade e a autonomia do paciente, devendo o médico ser responsabilizado. ${ }^{78}$

No afã de atender o paciente, correto nos seus desejos de ter uma morte digna, com menos sofrimentos, já que não há mais nada que possa impedi-la e no atendimento perfeito do fundamento constitucional da dignidade da pessoa humana, olvida-se que esse fundamento é da pessoa humana, que há nesse contrato duas delas e que não apenas uma merece respeito.

Atender-se-á corretamente aos justos desejos do paciente, estabelecendo-se, como bem lembra Dadalto o encaminhamento para outro profissional, cujas convicções íntimas não abalem sua necessária intervenção médica, na linha prevista pela Resolução 1995 de seu Conselho de Ordem e obedecendo ao que dispõe o Capítulo I, inciso XVII, do Código de Ética Médica, verbis:

O médico exercerá sua profissão com autonomia, não sendo obrigado a prestar serviços que contrariem os ditames de sua consciência ou a quem não deseje, excetuadas as situações de ausência de outro médico, em caso de urgência ou emergência, ou quando sua recusa possa trazer danos à saúde do paciente. (grifo nosso)

E o paciente deve ser cuidadosamente preparado para receber tal substituição, quando terá que ser-lhe dado tempo para entender a recusa do profissional anterior e a aceitar o novo profissional, com o qual deverá construir nova relação médico-paciente.

Dessa forma, acreditamos que dever-se-á acrescer ao $§ 2^{\circ}$ do art. 2 da Resolução 1995, a recusa do médico em levar em consideração as

\footnotetext{
${ }^{78}$ CRUZ, M.E.M. \& OLIVEIRA, R.A. A Licitude Civil da Prática da Ortotanásia por Médico em Respeito à Vontade Livre do Paciente. Bioética: Brasília: CFM, 2013, 21(3), p. 410.
} 
Diretivas Antecipadas de Vontade do paciente, quando alegar o direito constitucional ao imperativo de consciência.

O imperativo de consciência é, portanto, direito subjetivo fundamental, protegido pela Constituição da República Federativa do Brasil em vigor e tem que ser respeitado, não se admitindo a sua violação em qualquer situação, na melhor linha do direito à liberdade, direito esse explícito no caput do art. 5 da Lei Maior, que, em sendo desobedecido, ai sim, dará ensejo à responsabilização civil do violador, com o reconhecimento de dano moral.

O médico somente será responsabilizado, se após sua recusa lícita e legítima em seguir as Diretivas Antecipadas de Vontade de seu paciente, não permanecer presente no acompanhamento da prestação dos cuidados paliativos, dando a esse paciente a atenção e a segurança de que tais momentos são tão carentes.

Percebe-se que inúmeras são as questões que irão surgir entre as partes na celebração desse contrato tão humano e necessário no respeito à dignidade da pessoa humana. Percebe-se, também, que essas e outras questões a serem estabelecidas, conforme as discussões se aprofundem, situamse muito além da legitimidade médica para resolvê-las. São questões eminentemente jurídicas, pois envolvem, por exemplo, capacidade jurídica dos pacientes, como aqueles relativamente incapazes e não emancipados, embora os plenamente capazes também possam precisar de avaliação por perito médico-legal, devido a ação de medicamentos ou mesmo por influência da própria doença, como já mencionado acima.

Uma outra implicação jurídica importante refere-se ao registro e, consequente publicidade das Diretivas Antecipadas de Vontade. A Resolução do Conselho Federal de Medicina 1995/2012 refere que tal pode se dar, apenas, com o mero registro no prontuário do paciente pelo médico, mas deve-se lembrar de que ela tem valor de lei apenas entre a classe médica, já que o órgão de classe não tem competência jurídica para determinar o registro em cartório. Desta feita, torna-se claro que as Diretivas não estão legalizadas em nosso país, o que, em caso de tal assim se tornarem, permitirão que seja respeitada a vontade soberana dos pacientes, dando clara efetividade ao princípio da autonomia do paciente.

Tais questões e inúmeras outras que, certamente, irão surgir com o passar do tempo, demandam discussões muito mais profundas e extensas, mas que fogem ao escopo de nosso trabalho. Estamos ainda começando a conhecer esse novo instituto e muito há ainda a ser estudado. 


\section{CONSIDERAÇÕES FINAIS}

O estudo e a discussão, que enfrentamos nesse trabalho, visam, principalmente, discutir o conteúdo e algumas implicações jurídicas da Resolução 1955, da lavra do Conselho Federal de Medicina, de 31 de agosto de 2012, que trata das Diretivas Antecipadas de Vontade do Paciente, que veio preencher, pelo menos temporariamente, assim desejamos, a lacuna da legislação brasileira, sobre assunto tão caro a todos nós seres humanos: como nos comportar, médicos, pacientes e familiares, frente ao tratamento a ser dispensado aos pacientes terminais, sob o pálio do terceiro fundamento constitucional - a dignidade da pessoa humana.

Qualquer Resolução, oriunda do Conselhos de Medicina, somente determina o cumprimento aos seus profissionais médicos, entretanto, a necessidade de normatização do assunto em tela, sobrepõe-se à inexistência de determinação legislativa, posto que a demanda da sociedade nessa questão médica e, principalmente, humana, obriga a que sejam construídas orientações, como as dessa Resolução, àqueles envolvidos diretamente em tais situações, ou seja, médicos, pacientes e familiares, sem prejuízo de sua influência na sociedade como um todo.

$\mathrm{Na}$ análise da referida Resolução, entendemos que se trata, efetivamente, de um contrato de prestação de serviços médicos, com características bastante especiais, no que toca à parte do médico-assistente que, além do dever de informar, de forma detalhada e compreensível, a outra parte leiga, o estado real de sua doença, os métodos terapêuticos a serem utilizados e, principalmente, os inexistentes benefícios a serem com eles alcançados, acorda com esta parte, que se encontra em pleno exercício de suas faculdades mentais, e caso tal seja o seu real desejo, o emprego dos métodos terapêuticos paliativos.

Quanto à validade deste contrato, essa repousa na presença do pleno domínio pelo paciente, ou pelo seu representante legal, de capacidade indubitável de expressar, livremente e de forma autônoma, sua vontade. A manifestação de vontade do profissional médico deve, por seu turno, estar em consonância com a do paciente, ambos unidos numa declaração de vontade única, expressa em documento próprio e, por ambos, assinada.

O contrato das Diretivas Antecipadas de Vontade, igualmente, como não poderia deixar de ser, sob pena de invalidade, atende à função social, tanto entre as partes, quando médico e paciente necessitam estar em 
consonância durante momentos tão difíceis, em que se sobressaem a confiança por parte deste e a assistência médica e humana por parte daquele, como extrapartes, não apenas na influência sobre os familiares e amigos, que irão fornecer o suporte psicológico ao ente querido, mas igualmente à sociedade em geral, obrigada que será a repensar seu entendimento do que seja uma morte digna.

Em sendo um contrato de prazo indeterminado, cabe a ambas as partes, a qualquer momento de sua vigência, caso seja de seu desejo, promover a resilição unilateral, extinguindo-o, em um prazo justo, que atenda aos interesses da outra parte, obedecendo integralmente ao princípio legal da boa-fé objetiva.

Registramos igualmente aqui o verdadeiro respeito à autonomia do paciente, desde que esta encontra-se intimamente relacionada às ideias de indivíduo e de liberdade de pensamento, significando, portanto, que é o paciente que tem o poder de decisão sobre como deseja atravessar os seus momentos finais.

Dessa forma, repetimos, inteiramente consciente e corretamente informado sobre sua condição mórbida, com plena capacidade de entendimento do que está sendo informado pelo médico, sabedor de que poderá arrepender-se de sua decisão a qualquer momento que lhe parecer conveniente, o paciente estará exercendo, de livre e espontânea vontade, a sua autonomia como indivíduo.

Nessa linha de raciocínio, cabe, evidentemente, a preocupação com a influência das convicções íntimas do médico, no seu trabalho diário, como parte que efetivamente é, nesse contrato tão específico, quanto ao atendimento de pacientes vítimas de doenças graves, em seus estágios finais, que manifestem seus desejos de não mais serem submetidos a métodos de tratamento excepcionais, seja por meio de exames invasivos, seja por intervenções cirúrgicas, seja pela administração de medicamentos com graves efeitos colaterais e que não mais surtem efeitos positivos na evolução de seu quadro mórbido, apenas prolongando uma vida já sem sentido.

Podem-se observar recusas, de alguns médicos, em abandonar tais condutas médicas, pautadas pelo enorme desenvolvimento científicotecnológico da atualidade, condutas essas que, se em pacientes com grande possibilidade de vida apresentam resultados excelentes, em pacientes em estágios finais de doenças graves, não se observam, muitas vezes, quaisquer benefícios, pelo contrário, restam apenas mais dor e sofrimento, principalmente por conta dos graves efeitos colaterais que provocam. 
Esses profissionais, que apresentam severa resistência em abandonar tais condutas terapêuticas, por convicções pessoais e até mesmo religiosas, têm o direito fundamental constitucional de alegar imperativo de consciência para não seguir as Diretivas Antecipadas de Vontade, devendo ser substituídos por outro profissional não avesso a essas instruções. Entretanto, permanece a obrigação do profissional em continuar dando a atenção devida ao paciente e ministrando os cuidados paliativos.

Dessa forma, é nossa sugestão que a referida Resolução 1995/2012 do Conselho Federal de Medicina, faça o seguinte acréscimo (evidenciamos em negrito) ao texto do seu artigo $2^{\circ}$, $\$ 2^{\circ}$, verbis:

\begin{abstract}
Art. $\mathbf{2}^{\mathbf{0}} \mathbf{\$ 2}^{\mathbf{0}}$ : O médico deixará de levar em consideração as diretivas antecipadas de vontade do paciente ou representante que, em sua análise, estiverem em desacordo com os preceitos ditados pelo Código de Ética Médica e quando alegar o direito constitucional do imperativo de consciência.
\end{abstract}

No que se refere à denominação Testamento Vital, visto a Resolução 1995/2012, do CFM, intitulada Diretivas Antecipadas de Vontade, não mencionar, em nenhuma parte de seu texto, a palavra terminalidade, mas referir-se à incapacidade de expressão do paciente, situação que pode ser encontrada, como assinalamos, tanto no paciente no estágio final de sua existência, quanto naquele vítima de uma doença grave que, embora ainda não terminal, não possua esperanças de cura ou de mero alívio, mas que não lhe permita expressar sua opção pela forma de tratamento desejada, acreditamos que o termo Testamento Vital, mais utililizado no mundo jurídico, data vênia, deva ser substituído pelo Diretivas Antecipadas de Vontade, devido a sua maior adequação aos objetivos de que se reveste.

Quanto à forma da declaração de vontade deste contrato, é assentado que ela deverá ser expressa, contudo, embora a referida Resolução disponha que as Diretivas Antecipadas de Vontade devam ser registradas no prontuário médico, e tenhamos acrescentado que, por não ser o único documento médico utilizado na relação médico-paciente, igualmente a ficha médica poderá ser esse local, objetamos que, como tal contrato compõe objetivos diferentes do contrato ordinário de atendimento médico, sugerimos que seja ele feito por instrumento particular e apensado ao documento médico-base utilizado (prontuário médico ou ficha médica). 
Encerramos aqui esse pequeno estudo sobre a Resolução 1955/2012 do Conselho Federal de Medicina, que, respeitando o fundamento constitucional da Dignidade da Pessoa Humana, contempla precipuamente o princípio da Autonomia do Paciente, bem assim o atendimento ao Imperativo de Consciência do Médico, na melhor linha do nosso Direito Contemporâneo Pós-Positivista, que reproduz a personalização do nosso Direito Civil, encontrando-se este, por seu turno, iluminado pela Constituição da República Federativa do Brasil de 1988, a assim denominada Constituição Cidadã.

\section{REFERÊNCIAS BIBLIOGRÁFICAS}

ALBUQUERQUE, R.; GARRAFA, V. Autonomia e Indivíduos sem a Capacidade para Consentir: o caso dos menores de idade. Bioética. Brasília: CFM, 2016, 24(3).

ALMEIDA, José Luiz Telles de. Respeito à Autonomia do Paciente e Consentimento Livre e Esclarecido: uma abordagem principialista da relação médico-paciente. Cap. 2, Tese de Doutorado, Fundação Oswaldo Cruz, Escola Nacional de Saúde Pública: Rio de Janeiro, 1999. Disponível em http://portalteses.cict.fiocruz.br. Acesso em: 11 de maio de 2006.

ARENDT, Hannah. A Condição Humana. 10ª ed.. Rio de Janeiro: Forense Universitária, 2004.

AZEVEDO, A. J. Negócio Jurídico: Existência, Validade e Eficácia. 8a tir. São Paulo: Saraiva, 2013.

BEAUCHAMP, T. L. ; CHILDRESS, J. F. Principles of Biomedical Ethics. 5ed. New York: Oxford University Press Inc. 2001.

BRASIL. Código Civil e Empresarial. São Paulo: Saraiva, 2017.

Código de Ética Médica. 3ª ed. : São Paulo: Edipro, 2014.

BRASIL. Conselho Federal de Medicina. Dispõe sobre as diretivas antecipadas de vontade dos pacientes. Resolução no 1995, de 31 de agosto de 2012.

- Conselho Federal de Medicina. Resolução no 1805, de 25 de novembro de 2006.

- Constituição da República Federativa do Brasil. São Paulo: Saraiva, 2017.

. Justiça Federal. Seção Judiciária do Distrito Federal. Resolução 1805/2006. Brasília: CFM, 2006. Seção Judiciária do Distrito 
Federal. Ação Civil Pública 2007.34.00.014809-3, de 01 de dezembro de 2010. Dispõe sobre nova liminar, concedida por Juiz Federal, que suspende a anterior, conferindo legitimidade à Resolução CFM 1805/06. Relator: Roberto Luiz Luchi Demo. Disponível em: http://www.jfdf.jus.br/destaques/14\%20VARA_01\%2012\%202010 .pdf. Acesso em 03 de novembro de 2013.

BORGES, R. C B. Dos Direitos da Personalidade. in: Teoria Geral do Direito Civil. LOTUFO, R.L.; NANNI, G.E. (coord.) São Paulo: Atlas, 2008.

COELHO, M.E.M. \& FERRARA, A.C. Cuidados Paliativos: narrativas do sofrimento na escuta do outro. Bioética. Brasília: CFM, 2015, 23(2).

CRUZ, M.E.M. \& OLIVEIRA, R.A. A Licitude Civil da Prática da Ortotanásia por Médico em Respeito à Vontade Livre do Paciente. Bioética: Brasília: CFM, 2013, 21(3).

DADALTO, L. Reflexos Jurídicos da Resolução CFM 1995/2012. Bioética. Brasília: CFM, 2013. v.21(1).

- et al. Diretivas Antecipadas de Vontade: um modelo brasileiro. Bioética. Brasília, CFM, 2013, 21(3).

FARIAS, C.C. de \& ROSENVALD, N. Curso de Direito Civil: Contratos. 5 ${ }^{\mathrm{a}}$ ed. São Paulo: Atlas, 2015, v.4

. Curso de Direito Civil: Parte Geral e LINDB. 11ª ed. São Paulo: Atlas, 2013 . v.1

. Curso de Direito Civil: Parte Geral e LINDB. 13a ed. São Paulo: Atlas, 2015 . v.1

FERREIRA FILHO, M.G. apud GAGLIANO, P.S. e PAMPLONA FILHO, R. Novo Curso de Direito Civil: Parte Geral. 17ạ ed. São Paulo: Saraiva, 2015. v.1

GAGLiAnO, P.S. e PAMPLONA FILHO, R. Novo Curso de Direito Civil: Parte Geral. 17a ed. São Paulo: Saraiva, 2015. v.1.

. Novo Curso de Direito Civil: Contratos. Teoria Geral. 2 ${ }^{\mathrm{a}}$ ed. ver. atual. ref. São Paulo: Saraiva, 2006. v.4 (1).

. Novo Curso de Direito Civil: Contratos em espécie. São Paulo: Saraiva, 2008. v.4(2).

. Novo Curso de Direito Civil: Responsabilidade Civil. 4ㄹ ed. ver. atual. ref. São Paulo, jfdf.jus.br/destaques/o: Saraiva, 2006. v.3.

GONÇALVES, C.R. Direito Civil Brasileiro: Responsabilidade Civil. $2^{\mathrm{a}}$ ed. ver. atual. São Paulo: Saraiva, 2007. v.4. 
GOUVEIA, L.R. Diretivas Antecipadas de Vontade: um contrato de vida digna. 2013. 49 fls. Trabalho de Conclusão de Curso de PósGraduação lato sensu em Direito Civil Geral, Universidade Anhanguera-Uniderp, Rio de Janeiro, RJ.

Educação Médica: O Papel da Responsabilidade Médica no Ensino Médico de Graduação. 2007. 157f. Tese (Doutorado em Educação). Faculdade de Educação. UFRJ. Rio de Janeiro.

JONAS, H. O Princípio Vida. Petrópolis: Vozes, 2004, p. 19.

KOVÁCS, M.J. Pesquisa com Pacientes Gravemente Enfermos: autonomia, riscos, benefícios e dignidade. Bioética. Brasília: CFM, 2009. v.17(2).

MARQUES, C.L.; BENJAMIN, A.H.V.; MIRAGEM, B. Comentários ao Código de Defesa do Consumidor. 3ed. rev. atual. amp. São Paulo: RT, 2010.

MARREIRO, C.L. Responsabilidade Civil do Médico na Prática da Distanásia. Bioética. Brasília: CFM, 2013. v.21(2).

MORAES, A. de. Constituição do Brasil Interpretada e Legislação Constitucional. 8a ed. São Paulo: Atlas, 2011.

MORAES, G.P. de. Curso de Direito Constitucional. $2^{a}$ ed. Niterói: Impetus, 2008.

OLIVEIRA, M.Z.P.B.; BARBAS, Stela. Autonomia do Idoso e Distanásia. Bioética. Brasília: CFM, 2013. v.21(2)

PIMENTA BUENO, J.A. apud SILVA, J.A. da. Curso de Direito Constitucional Positivo. 18 ${ }^{\mathrm{a}}$ ed. São Paulo: Malheiros Editores, 2000.

SAUWEN, R.F. ; HRYNIEWICZ, S. O Direito "in vitro": Da Bioética ao Biodireito. 2ed. Rio de Janeiro: Lumen Juris, 2000.

SCHREIBER, A. Direitos da Personalidade. São Paulo: Atlas, 2011.

SEGRE, Marco. Ensino da Bioética lato sensu. In: Bioética. Vol. 11, n. 2. Brasília: CFM, 2003.

VIEIRA, A. Índice das Coisas Mais Notáveis. In: PÉCORA, A. (org.) São Paulo: Hedra, 2010, p.248.

VILLAS-BÔAS, M.E. A Ortotanásia e o Direito Penal Brasileiro. Bioética. Brasília: CFM, 2008. v.16(1).

TARTUCE, F. Direito Civil: Teoria Geral dos Contratos e Contratos em Espécie. 8ed. ver. atual. amp. São Paulo: Método, 2013. v.3.

TARTUCE, F. A Função Social dos Contratos, a Boa-Fé objetiva e as Recentes Súmulas do Superior Tribunal de Justiça. A Função Social 
dos Contratos: Do Código de Defesa do Consumidor ao Novo Código Civil. São Paulo: Método, 2005.

VIEIRA, A. Índice das Coisas Mais Notáveis. In: PÉCORA, A. (org.) São Paulo: Hedra, 2010, p.248.

VOLTAIRE (François Marie Arouet). Dicionário Filosófico. São Paulo: Editora Martin Claret, 2002. 
